\title{
A SYSTEMATIC MIXED STUDIES REVIEW OF PATIENT EXPERIENCES IN THE EMERGENCY DEPARTMENT
}

Claudia Bul1 ${ }^{1}$, Sharon Latimer ${ }^{1,2,3}$, Julia Crilly ${ }^{1,2,3}$ \& Brigid M Gillespie ${ }^{1,2,3}$

${ }^{1}$ School of Nursing and Midwifery, Griffith University, Southport, 4215, Queensland, Australia

${ }^{2}$ Gold Coast Hospital and Health Service, Southport, 4215, Queensland, Australia

${ }^{3}$ Menzies Health Institute Queensland, Griffith University, Southport 4215, Queensland, Australia

Corresponding author: Miss Claudia Bull, BNutr(Hons), PhD Candidate

Room 2.14A, Building G01, Griffith University, Gold Coast Campus, 1 Parklands Drive, Southport, Queensland, 4215, Australia

Email: claudia.bull@griffithuni.edu.au

Phone: (+610) 439791446

Keywords: emergency department; interpersonal; quality

Word count: 3,830 


\begin{abstract}
Background: Understanding patient experiences is crucial to evaluating care quality in Emergency Departments. However, while previous reviews describe the determinants of Emergency Department patient experiences (i.e. factors that influence patient experiences), few have described actual patient experiences. The aim of this systematic mixed studies review was to describe patient experiences in the Emergency Department from the patient's perspective.
\end{abstract}

Methods: EMBASE, MEDLINE, ProQuest Nursing and Allied Health, CINAHL and the Cochrane Library electronic databases were searched, with publication dates limited between January 1, 2001 - September 16, 2019. Studies describing adult patient experiences in the Emergency Department were included. Studies describing patient satisfaction, proxy-reported experiences or child/adolescent experiences were excluded. The quality of included studies was appraised using the Mixed Methods Appraisal Tool (2018 version). An inductive, convergent qualitative synthesis of the extracted data was undertaken following Thomas and Harden's (2008) methods.

Results: Fifty-four studies were included and of those, only five (9\%) studies included a standardised definition of patient experience. Two inter-related themes emerged: Relationships between Emergency Department patients and care providers; and Spending time in the Emergency Department environment. The first theme included four sub-themes regarding respect, communication, caring behaviours, and optimising patient confidence. A key finding related to the potential for power imbalances between patients and their care providers. The second theme included two sub-themes regarding physical aspects of the Emergency Department environment and patients' waiting experience. Patients attributed more importance to the waiting experience itself rather than the duration they had to wait. 
Conclusions: Patients in the Emergency Department have unique and complex experiences. Greater research is needed to understand the relational and environmental factors that contribute to power imbalances between patients and care providers, how to support more positive waiting experiences, and developing a standardised definition of patient experience in the Emergency Department.

Review registration number: CRD42020150154 (PROSPERO) 


\section{WHAT IS KNOWN ON THIS SUBJECT:}

- Optimising patient experiences is associated with improved patient safety and clinical outcomes, reduced health service utilisation, and is recognised as a critical measure of healthcare quality.

- Patient experiences in the Emergency Department (ED) are gaining interest as EDs often serve as the front door to other hospital services and are universally recognised for having a high workload.

- Patient experiences in the ED are poorly understood, impacting our ability to conceptualise and measure them.

\section{WHAT THIS STUDY ADDS:}

- Patient experiences in the ED are complex and best conceptualised by interplay between patients, care providers and the ED environment.

- Our findings reveal that power imbalances underscore some ED patient-care provider relationships, which may be exacerbated by the inherent complexities and fast-paced care delivered in ED environments.

- The psychological experience of waiting in the ED appears to be more important to patients than the duration of the wait itself. 


\section{INTRODUCTION}

Patient experience in the Emergency Department (ED) is one area of patient-centred care provision that continues to garner attention. EDs are often the first point of contact for unwell patients entering hospital, and present unique challenges to providing optimal care experiences. This may be due to ED patients' heightened sense of fear and distress; [1] the anxiety associated with not knowing the type of treatment they may receive;[2] crowded and often chaotic environments; $[3,4]$ or a combination of these factors. ED staff also experience challenges associated with ambulance ramping (the inability of paramedics to transfer patients' clinical care to the ED),[5-7] delays in accessing in-patient beds,[8] ED overcrowding, $[9,10]$ and patient violence directed towards staff; $[11]$ all of which can directly and indirectly impact on patient experiences. Given the unique complexities associated with providing and receiving ED care, measuring and optimising patient experiences is a priority for many health service managers and organisational leaders globally.[12-14]

A primary challenge associated with measuring patient experiences in the ED is that we currently do not have a robust understanding of the core themes of ED patient experiences. Poor conceptualisation has limited robust measurement of patient experience in the ED. Recent reviews have reported the common determinants of ED patient experiences, $[12,15]$ such as how wait time affects experiences of care. Yet, while existing reviews enable us to understand the factors that control or influence patient experiences in the ED, they do not describe actual experiences in the ED. This is a crucial and necessary step towards operationalising (measuring) a concept.[16]

There is also ongoing confusion related to the interchangeable use of 'patient experience' and 'patient satisfaction' in the literature. $[13,15,17,18]$ There is agreement that the 'patient experience' encompasses what happened during a care encounter and how it happened from 
the patient's perspective.[19-25] Alternatively, 'patient satisfaction' can be defined as whether the care a patient received did or did not meet their expectations.[26, 27] These two concepts are also operationalised differently. Unlike satisfaction measures, patient experiences provide actionable feedback to health services about what can improve care experiences, thereby optimising the opportunity to provide patient-centred care.

Thus, given the limitations present in the ED patient experiences literature, the aim of this systematic mixed studies review was to describe patient experiences in the Emergency Department from the patient's perspective.

\section{METHODS}

\section{Study design}

This systematic mixed studies review followed the 7-step approach proposed by Pluye and Hong (2014).[28] Reporting was guided by the Preferred Reporting Items for Systematic Reviews and Meta-Analyses (PRISMA) checklist,[29] and registered with the international prospective register of systematic reviews (PROSPERO) (ID: CRD42020150154).[30]

\section{Patient and public involvement}

No patient/public involvement.

Step 1: Formulate a review question

This SMSR has three research questions: (i) how has 'patient experience' been defined in the ED literature; (ii) how do patients describe their experiences in the ED; and (iii) what is the quality of studies reporting on patient experiences in the ED. We define 'patient experience' as what happened during a care encounter and how it was perceived by the patient.[19-25]

Step 2: Define eligibility criteria 
Table 1 outlines the eligibility criteria applied to studies identified through electronic database searching.

TABLE 1: SMSR eligibility criteria for the inclusion and exclusion of studies

\section{Studies were included if:}

- Patient experiences in the ED were outlined in the study aims/ objectives (or)

- Study authors distinguished between the concepts of patient experience and patient satisfaction, and identified that their focus was on patient experience (or)

- Survey instruments were patient experience surveys or patient-reported experience measures (PREMs) (or)

- Survey instruments were developed with the intention of capturing patient experiences

- Participants were adults (the legal age of adulthood differs internationally and across contexts, so we accepted study authors' definition of adulthood)

\section{Studies were excluded if:}

- Patient satisfaction or patient expectation was outlined in the study aims/ objectives (or)

- Survey instruments were developed with the intention of capturing patient satisfaction

- Studies were conducted in settings other than the ED (e.g. inpatient, prehospital, outpatient)

- Patients were children, adolescents or young adults (as defined by study authors)

- Patient experience data was proxy-reported (e.g. carer on behalf of a patient) or was unable to be extracted independently of proxy-reported data

- Presented literature reviews, meta-reviews or quality improvement (QI) activities

- Published between January $1^{\text {st }}, 2001$ (publication year of the Crossing the Quality Chasm report)[31] and September $16^{\text {th }}, 2019$

- Published in English

- Published in peer-reviewed journals

- Primary research

SMSR = Systematic Mixed Studies Review; ED = Emergency Department; PREM = Patient-reported experience measure; QI = Quality Improvement

Step 3: Apply an extensive search strategy

The following electronic databases were systematically searched for studies published between January $1^{\text {st }}, 2001$ and September $16^{\text {th }}, 2019$ : EMBASE (via Elsevier), MEDLINE (via Ovid), ProQuest Nursing and Allied Health, CINAHL (via EBSCOhost) and the Cochrane Library. Searches used Medical Subject Headings (MeSH) where appropriate, Boolean operators (AND, OR), and proximity searching in accordance with the specifications 
of the databases. A university health librarian was consulted prior to undertaking the final database searches. Supplementary file 1 contains the full search strategy for all electronic databases.

Steps 4 and 5: Identify and select potentially relevant studies

In September 2019, one author (CB) performed electronic database searching. Search results were imported into EndNote (Version X9.2, Clarivate Analytics) and duplicates removed. Using the inclusion and exclusion criteria (step 2), two authors (CB, SL) undertook title and abstract screening independently. Articles that appeared to meet the eligibility criteria or were unable to be excluded based on title and abstract screening alone underwent independent fulltext review $(\mathrm{CB}, \mathrm{SL})$. Discrepancies regarding the inclusion or exclusion of an article were discussed and adjudicated by a third author (BG), where necessary.

Step 6: Appraise the quality of included studies

The Mixed Methods Appraisal Tool (MMAT, 2018 version) was used to assess the methodological quality of the included studies.[32] The MMAT allows researchers to appraise five research designs (qualitative research, randomised controlled trials, nonrandomised studies, quantitative descriptive studies, and mixed methods studies) based on whether design-specific criteria are met ('Yes', 'No' and 'Can't tell').[32] Two authors (CB, SL) independently appraised the quality of included studies using the MMAT. Discrepancies between scores were first discussed between the appraising authors, and where necessary, adjudicated by a third author (BG). An inter-rater reliability (Kappa) score was calculated to ascertain the strength of agreement between the two authors' ratings.[33]

Step 7: Synthesise included studies

Verbatim data extraction of the included studies was undertaken by one author $(\mathrm{CB})$ into a standardised extraction template, and cross-checked by another author (SL, BG, JC); 
ensuring data accuracy and enabling all authors the opportunity to develop a comprehensive understanding of the literature. An inductive, convergent qualitative synthesis approach was used to transform all data into qualitative findings.[28] One author (CB) led the results synthesis using Thomas and Harden's (2008) methods for thematic synthesis[34] by first undertaking line-by-line coding, organising codes into groups, and subsequently developing the initial descriptive sub-themes and themes. Throughout this process, the lead author (CB) maintained detailed analytical audit trails and met frequently with the research team (SL, JC and BG) to discuss the analysis. During these meetings, authors discussed revisions to codes and their groupings, and collectively developed the final sub-themes and themes. The development of the final sub-themes and themes involved abstracting concepts of patient experiences in the ED based on the findings of the primary studies.[34]

\section{RESULTS}

\section{Summary of included studies}

Fifty-four studies were included in this review (Figure 1), which are summarised in Table 2. Twenty-six (48\%) were qualitative studies, 23 (43\%) were quantitative studies and five (9\%) were mixed-methods studies (Supplementary File 2). Most studies were conducted in the US $(\mathrm{n}=29 ; 35 \%)$ and half (50\%) were published between January 2016 - September 2019. Patient populations varied substantially in age and reason for ED presentation. MMAT scores are presented separately in Supplementary File 3 demonstrating how the included studies scored against established criterion for the different study designs. Inter-rater reliability for MMAT scoring was 0.78 (substantial agreement).[33]

[INSERT FIGURE 1 ABOUT HERE]

\section{Definitions of 'patient experience'}


Researchers in five $(9 \%)$ of the 54 studies provided a definition of patient experience (Supplementary File 4).[35-39] Three studies defined patient experience in relation to why it is a preferable measure for quality improvement as opposed to patient satisfaction.[35, 36, 39] These definitions stated that patient experiences "have shown to be more objective and to yield more detailed information for quality improvement" $[35,36]$ as they "provide information identifying where in the process problems may reside and what can be done to improve patient care”.[39] In articulating the difference between patient experience and patient satisfaction, one study also stated that patient satisfaction is based on "expectations (or 'needs') and experiences" where "expectations are related to personal preferences, which make quality of care difficult to measure".[35]

Another study proposed a patient experience definition based on the domains addressed by the patient experience survey they employed.[37] These domains included staff care, pain management, discharge communication, respect, medication communication, and wait time and crowding.[37] Another study defined the patient experience as a combination of “'functional' aspects of care (such as arranging the transfer of patients to other services, administering medication and helping patients to manage and control pain), 'transactional' aspects of care (in which the individual is cared 'for', e.g., meeting the preferences of the patient as far as timings and locations of appointments are concerned) and 'relational' aspects of care (where the individual is cared 'about', e.g., care is approached as part of an ongoing relationship with the patient)'.[38]

\section{Thematic synthesis}

Two overarching themes emerged: Relationships between Emergency Department patients and care providers, and Spending time in the Emergency Department environment (Table 2). There is overlap between these themes due to the complex interplay between patients, care 
providers and the ED environment. The overlap contributes to a unified and holistic conceptualisation of patient experiences in the ED.

Theme 1: Relationships between Emergency Department patients and care providers

The theme Relationships between Emergency Department patients and care providers included four sub-themes: Respecting patients; Communicating with patients to keep them informed; Caring for patients; and Building and maintaining patients' confidence (Table 2).

The overarching theme describes the unique relationship dynamics between ED patients and care providers, and the perceived distribution of power. ED patients acknowledged that relational power exists between themselves and their care providers, who possessed valuable medical knowledge and determined the type and timing of their treatment. Furthermore, the actions of some care providers significantly influenced how patients felt about themselves, causing some to question the validity of their ED presentation. These ED patients reported feeling like a “burden”,[40] “dehumanised”,[41-43] and “powerless”,[41,44] indicating that the relational power tipped in favour of care providers, and negatively impacted patient experiences. In turn, this influenced the behaviour patients exhibited toward their care providers with some becoming frustrated and angry. Other patients changed their behaviour so they could be viewed as the "best patient possible”,[45] "compliant”,[41] and avoid “adding to staff stress".[46] Further, some patients welcomed the "passive”[46] patient role because of their presenting condition (e.g. trauma resuscitation). When an equal distribution of relational power existed between patients and care providers, the majority of patients felt included and treated like a "human being" instead of a "case" or "number".[41, 43, 47, 48] Care providers use of inclusive language made patients feel valued and involved in their care, contributing to positive patient experiences.[41, 49, 50]

\section{Subthemes}




\section{Respecting patients}

Respect was described by patients as the behaviours exhibited by care providers that considered their feelings, wishes and rights. The degree of respect patients received impacted on their sense of worth, power and vulnerability,[41, 42, 49] which influenced their care experience in the ED. Respect was demonstrated on a spectrum, ranging from a lack of respect to a high level of respect. Positive experiences were associated with being listened to carefully and attentively,[35-37, 40, 46, 47, 50-60] having the opportunity to talk uninterrupted, $[47,50]$ being taken seriously, $[36,45,49,51,61,62]$ and feeling as though care providers had the time for them. $[51,53,55,59,60,63,64]$ Similarly, care providers that were on the same level as patients (i.e. down-to-earth) $[41,47,65]$ and established rapport with patients and their family[41, 47, 50, 66-70] also positively impacted patient experiences. However, when relational respect was minimal or absent, patients reported more negative experiences. This occurred when ED care providers talked in front of patients as if they were not there, $[37,58,68,70,71]$ when patients felt they were not taken seriously, $[45,63,65,66$, 72] were disregarded,[45, 73] treated with judgement or discrimination, $[41,42,45,68,72$, 74] or humiliated.[41, 45, 62, 74]

\section{Communicating with patients to keep them informed}

This sub-theme of patient experience involved the transfer or exchange of information between care providers and patients. Most communication was one-way where care providers would provide instruction to patients. Yet, there was also some evidence of discussion, suggesting patient involvement and partnership in their ED care. Patient experiences were optimised when care providers delivered the right amount of information in an understandable way, [35-37, 47, 50-55, 57, 58, 60-62, 65, 67, 69, 70, 75-78] when they communicated with empathy and compassion, $[47,49,56,68,69,79]$ when patients were 
informed about care processes and treatment options, $[46,49,52,56,62,65,68,69,72,80]$ updated throughout their ED journey,[39, 66, 69] were able to discuss matters that were important to them, $[35-37,47,52,54,67,68]$ and were encouraged to talk and ask questions.[50, 65, 69] Generally, patients who felt informed by their care providers, reported better experiences characterised by feeling reassured, safe and confident.[46, 48, 49, 69, 72] Patients who felt uninformed however, reported poorer experiences characterised by anxiety, confusion and fear.[39, 40, 43, 63, 72] Patients described being uninformed as not being provided with sufficient verbal or written information about matters such as how long they might have to wait and what to do following discharge,[36, 39, 41, 46, 52, 56, 58, 60, 61, 63, $65,72,81-83]$ receiving information they could not understand, $[46,63,68]$ when information was delivered abruptly, $[68,81,82]$ when information from multiple care providers was inconsistent or contradictory, $[36,42,58,60,78]$ and when they were asked to repeat themselves numerous times.[42, 45, 61, 66]

\section{Caring for patients}

Being cared for encompassed both routine/ functional aspects of care (e.g. tests, examinations and procedures; appropriate pain relief and management; and treatment or transfer),[35-42, $44-47,49,52,54-56,60,63-65,67,68,72,74,77,80,82,84,85]$ and emotional aspects of care. However, receiving either functional or emotional care in the absence of the other resulted in poorer patient experiences. Patients valued emotional aspects of care as it made them feel important and understood by their care providers,[40, 48, 49, 65, 81] such as when empathy and genuine concern was demonstrated.[38-40, 43, 45, 47, 49, 56, 60, 65, 81, 82, 86] This occurred when care providers used reassuring words, touch and body language,[40, $41,47,49,68,79]$ when they informed patients' family or friends that they were in the ED, $[48,49,61,68,75,82]$ and by ensuring patients did not feel lonely.[37, 40, 48, 49, 64, $68,80-82]$ Receiving an inadequate level of emotional support[40, 43, 44, 49, 65, 72, 73] or 
follow-up support (e.g. counselling, social work)[65, 67, 73, 82$]$ had negative impacts on patient experiences.

\section{Building and maintaining patients' confidence}

Patients described how their care providers instilled and preserved a sense of confidence in them and the care they provided. Patients who felt confident in their care providers reported feeling safer.[48, 68, 78] Confidence was instilled when care providers demonstrated competence, knowledge and skill,[36, 40, 41, 46, 47, 49, 52, 56, 60, 65, 68, 69, 78, 87] took responsibility for and control of patients' care,[39, 41, 49, 61, 88] were efficient and responsive,[37, 40, 41, 45, 48, 49, 56, 66, 68, 69, 73, 84, 87] and when care providers operated as a team. $[38,41,43,46,48,49,68]$ Yet, when patient confidence in their care providers was challenged, they reported poorer experiences because they felt they could no longer trust their care providers.[41, 64] Patients' confidence diminished when care providers failed to demonstrate adequate competence, knowledge and skill,[42, 60, 65, 66, 68, 74] when care felt disjointed,[41, 46, 60, 61, 69] and when care providers failed to take responsibility for patients' care.[41, 46, 61, 88]

Theme 2: Spending time in the Emergency Department environment

The theme Spending time in the Emergency Department environment included two subthemes: Being aware of physical aspects of the Emergency Department environment; and Waiting in the Emergency Department environment (Table 2).

The overarching theme describes patient experiences related to the physical attributes of the care environment (e.g. comfort and privacy), and the psychological experience of waiting in the ED. Patients experiencing long waiting times were more aware of their physical environment "because [they] ha[d] nothing else to do".[80] Hence, characteristics such as equipment wear and tear,[80] cleanliness, $[39,48,58,80]$ noise, $[48,51,65]$ and the health 
condition of other patients $[39,87]$ were more noticeable. Patients who spent less time in the ED tended to report less about the physical aspects of the ED environment, instead focussing more on their relationships with care providers.[49, 68, 82] Some patients who experienced longer ED waiting times perceived that care providers had forgotten or abandoned them, especially if they received limited information regarding the reasons why they were waiting.[40, 43, 44, 46, 72] Thus, the ED environment influenced how patients perceived the humanistic characteristics of their care providers.

\section{Subthemes}

Being aware of physical aspects of the Emergency Department environment

Patients described how the physical (structural, spatial, and material) characteristics of the ED environment impacted their experience. Patients reported better experiences when the ED was clean and hygienic, $[35,36,39,48,51,52,54,58,67,80,88]$ when they were physically comfortable (e.g. had comfortable seating, blankets),[37-39, 48, 68, 78, 80, 88] were able to access a range of amenities (e.g. bathroom, food, drink, TVs, and magazines),[36, 39, 42, 63, $67-69,78,80,88]$ and received an adequate level of privacy during physical examinations, procedures and discussions in the ED. $[35,42,52,58,63,71,86,87]$ However, the physical ED environment could also negatively impact patient experiences, such as when patients reported feeling uncomfortable in the ED unrelated to pain (e.g. cold and draughty corridors, small beds), $[80,88]$ being surrounded by too many other people[37, 43, 49, 65, 68, 80, 83 , $88]$ and a lot of noise, $[48,65,88]$ not receiving an adequate level of privacy during physical examinations, procedures and discussions, $[39,42,63-65,73,87]$ and being unable to access adequate amenities (e.g. bathrooms, food, drink, and wheelchairs).[39-41, 69, 74, 80]

Waiting in the Emergency Department environment 
Patients acknowledged that 'waiting' would be an important part of their ED experience. However, some patients felt mislead by the idea of a single "designated" waiting area,[56, 80] as waiting was not restricted to just the waiting room. They reported that having distractions (e.g. TVs, magazines, company) during long waits, $[64,80]$ and being informed about why they were waiting or the order in which they would be seen relative to other patients, $[36,49,58,64,76]$ positively impacted their experience. Receiving care quickly was also associated with better patient experiences, $[40,51,56,63,66,69]$ however, it was relatively uncommon for patients to report short wait times. When this did occur, it came as a pleasant and unexpected surprise to patients.[56,69] Patients who perceived that their wait was too long, $[39,42,44-46,56,60,62,64-66,72,73,80,83,84,88]$ waited in areas other than the actual waiting room, $[39,40,56,60,73,80,88]$ and waited without knowing why they were waiting, $[39,40,43,44,46,56,63,72,83]$ reported worse experiences as they became frustrated and felt abandoned by their ED care providers. [43, 44, 56, 88] 
TABLE 2: Quotes extracted from included studies representing the themes and sub-themes of patient experience in the ED

\begin{tabular}{|c|c|}
\hline Themes and sub-themes & Quotes extracted from included studies \\
\hline \multicolumn{2}{|c|}{ Relationships between Emergency Department patients and care providers } \\
\hline Respecting patients & $\begin{array}{l}\text { - "... He listened carefully to me. ... I was very happy he listened to me." [47] } \\
\text { - "What I liked about Dr. X was his kindness and his willingness to talk and to explain things—he was good like that." [60] } \\
\text { - "I felt like I was being taken seriously...” [36, 62] } \\
\text { - "... the worst time of my life, is the time walking in the emergency door and [being] told I sought medication." [45] } \\
\text { - "... [the nurses said] things like how it [being transgender] was against God and just wasn't right." [74] }\end{array}$ \\
\hline $\begin{array}{l}\text { Communicating with patients } \\
\text { to keep them informed }\end{array}$ & $\begin{array}{l}\text { - "They explained to me in the plainest language that I could understand, what they were doing, what was wrong with me, what I } \\
\text { - was there for. I understood everything that they said to me." [47] } \\
\text { "They explained to me what would happen, that I had three options, I could get the D\&C, I could go home and just let it happen on } \\
\text { - its own, or I could have surgery." [72] } \\
\text { - "... the nurse encouraged me and supported me in telling about the act of violence." [65] } \\
\text { - "Yhey didn't tell me anything and they were really scaring me." [72] } \\
\text { "You spend twelve hours saying the same thing." [66] }\end{array}$ \\
\hline Caring for patients & $\begin{array}{l}\text { - "I was by myself in the emergency room so I just felt horrible and there was nobody there and you know it was really bad. You } \\
\text { - know, the nurse she was really nice and she showed a lot of empathy for me. She told me, 'It's going to be okay.," [81] } \\
\text {... a non-purposeful touch that conveyed caring and reassurance was an essential component of patients feeling an overriding sense } \\
\text { of being safe.[49] } \\
\text { - ... negative emotions associated with being alone were allayed if the patients saw staff present.[49] } \\
\text { "... I remember feeling like they understood that this was a dead baby for me even though it wasn't. I think they at least understood } \\
\text { that it was a loss. So I felt really like they got it." [82] } \\
\text { "I was very disappointed that I was not offered to talk to someone, it just kind of disappeared. It would have been good if they had } \\
\text { a few routines... after I had returned home [I] realized that I needed to talk." [73] }\end{array}$ \\
\hline $\begin{array}{l}\text { Building and maintaining } \\
\text { patients' confidence }\end{array}$ & $\begin{array}{l}\text { - "When [the team] took control ... I felt more safe..." [68] } \\
\text { - "In ED they were all in harmony with each other... They all had a job to do and they did it, in sequence and sometimes in parallel, } \\
\text { they just knew what to do and they did it." [48] } \\
\text {-.. feelings of being vulnerable can be minimized through the actions of staff that demonstrate they are in control and can be } \\
\text { trusted.[49] } \\
\text { "The pain team said I need to get the depression addressed, and the CAT team said 'you need to get your migraines fixed'... I just } \\
\text { burst into tears and said I can't connect up all the dots, I can't connect you all up." [41] } \\
\text { "The wait was so long. They [nurses] kept telling me tonight, this evening, no, no tomorrow morning ... I couldn't believe them } \\
\text { anymore. So finally when they came to bring me to the surgery room... I couldn't trust them anymore." [64] }\end{array}$ \\
\hline & partment environment \\
\hline
\end{tabular}


Being aware of physical aspects of the Emergency Department environment

Waiting in the Emergency
Department environment

Waiting in the Emergency
Department environment

- "Clean, comfortable... it made me feel safe." [48]

- "I was taken to one of the assessment rooms and not to the main part of the emergency department but to a room which was a more private room that was walled rather than just curtains. " [63]

- “... I'm 6'3" and I'm in a 5 foot something bed. It's uncomfortable..." [88]

- "The reason is that we didn't get sleep in the emergency because everybody was talking and there is no privacy. " [64]

- "Every single patient around the waiting room must have heard the doctor ask if my husband had punched me." [65]

- ... magazines or a television facilitating the waiting are largely appreciated. Without them, patients feel neglected.[80]

- “... Some people were sicker than I was and so I had to wait for my turn, and that was ok with me.” [64]

- "I was told how long I'd have to wait." [61]

- "This is not the first time I've been here and was so ill and had to sit and wait. Then, when I get to the next spot, I have to sit and wait. Then they [the EM physicians] come in and out for a second, and then you have to wait again." [60]

- “... A lady sitting in the waiting room looks dreadful from pain, she was given nothing ..." [39] 


\section{DISCUSSION}

The aim of this systematic mixed studies review was to describe patient experiences in the Emergency Department from the patient's perspective based on the current literature. Our findings suggest that ED patient experiences can be described in terms of two overarching and interrelated themes: Relationships between Emergency Department patients and care providers, and Spending time in the Emergency Department environment. The overlap between these themes represents the interaction between patients, care providers and the ED environment that is central to patient experiences in the ED.

A key finding of this review was that the concept of patient experience was rarely defined in the included studies. Most definitions articulated how patient experience differs to patient satisfaction. Yet, while this contributes to clearer conceptual boundaries between the two concepts, it fails to clarify exactly what the ED patient experience $i s$. The lack of a standardised patient experience definition has significant implications including making it difficult to compare and contrast research findings. This limits the effective measurement of patient experiences and provides limited foundation upon which to design future research and quality improvement activities that aim to optimise patient experiences. Previous research proposed that patient experiences (irrespective of the healthcare context) span across the continuum of care, go beyond survey results, align with patient-centred care principles and focus on individualised care.[89] However, while the authors suggested that patient experiences comprise "more than satisfaction",[89] they also recommended that a definition of patient experience should focus on expectations; an inherent determinant of patient satisfaction.[90] Consequently, more comprehensive investigations are required to generate a standardised conceptual definition of patient experience. It will also be important to understand whether differences between healthcare settings impact how we conceptualise the patient experience. 
The review findings also highlight the importance of patient-care provider relationships in the ED. This has been evidenced numerous times in the literature, particularly regarding the importance of effective communication.[91-94] However, our review revealed a novel insight into ED patient-care provider relationships - underlying many patient experiences in the ED are unequal distributions of power between patients and their care providers. Some patients felt they had to prove their worth and compete to gain ED care providers' time by presenting themselves as the best possible patient, adopting passive and compliant behaviours, and not being burdensome by asking questions when the ED staff appeared busy. Relational power imbalances did not appear to be deliberate on the part of the care providers and arose due to the inherent complexities associated with EDs as healthcare services. Higher levels of patient anxiety,[95] more acute/ urgent patient conditions,[1] longer waiting times prior to receiving care,[96] and the escalating busyness of $\mathrm{EDs}[97]$ all contribute to patients having minimal control over their health and personal circumstances while in the ED. Moreover, many EDs are driven by organisational efficiency pressures (e.g. discharging ED patients within an allocated period of time) and the need to prioritise life-saving medical care in emergency situations.[98-100] These factors may momentarily override the ability of ED care providers to optimise a more patient-centred approach to care for some patients, and suggests that EDs are not conducive to maintaining equal power distributions.

Patient involvement in shared decision-making regarding their care was minimally discussed in the included studies, further evidencing ED patient-care provider power imbalances. It has been asserted that patients are more susceptible to a "doctor knowns best" mentality in the ED because it is a high stakes care environment where decisions may have significant impacts on the patient's health and wellbeing.[101] This is despite mounting evidence that shared-decision making can positively impact patient experiences of care and their overall health outcomes.[102] While support for shared-decision making initiatives in the ED 
continues to grow,[103-112] the impact of shared-decision making on ED patient experiences is yet to be examined; warranting further research.

This review highlights that patients placed more importance on their psychological experience of waiting than the actual wait time. EDs globally are becoming increasingly busy. In Australia for example, the annual rate of ED presentations exceeds that of population growth $(3.4 \%$ versus $1.4 \%$, respectively). $[113,114]$ One explanation for this increase is that EDs in many countries serve as a safety net for low-income and socially disadvantaged citizens who are unable to afford or access community healthcare.[115] In turn, increased utilisation of ED services culminates in longer ED wait times. In our study, as in other studies, patients anticipated and accepted that an ED visit would involve a wait,[15] but that being provided information during the wait was crucial to mitigating patients' feelings of frustration, humiliation, and powerlessness.[116, 117] Yet, much of the research about ED waiting relates to differences between perceived and actual wait times.[39, 118-121] The patient's psychological experience of waiting has comparably received little attention, and warrants greater exploration. This finding also challenges the utility of capturing waiting times as part of patient experience evaluations.

\section{Limitations}

Like all reviews, this review has limitations. First, despite systematic and rigorous searching, articles may have been missed. However, the assistance of a qualified health librarian during the development of our database search strategy was sought to minimise this risk. Second, grey sources of literature were not considered for inclusion due to their questionable quality (i.e. not peer-reviewed) and potential risk of bias. Third, there was a paucity of literature pertaining to the ED experiences of culturally and linguistically diverse patients, indigenous peoples, and patients with mental health problems. These gaps suggest that our conceptual 
understanding of ED patient experiences is not inclusive of all perspectives, and highlights areas of research that warrant greater attention. Finally, we excluded studies including proxyreported experiences in the ED as this did not align with the review's aim of describing patient experiences in the ED. However, proxy-reported experiences may be the only accounts available for patients with disability and cognitive impairment. As such, while this was not within the scope of the current review, this is an area that warrants greater research.

\section{CONCLUSION}

A standardised conceptual definition of patient experience is needed. This review identifies two inter-related themes regarding patient experience in the ED: Relationships between ED patients and care providers, and Spending time in the ED environment. Circumstances inherent in the ED visit can contribute to power imbalances between ED patients and their care providers, which can affect patient experiences and behaviours. The waiting experience, rather than the length of the wait, can also contribute to the patient experience, particularly whether they feel valued and cared for. Understanding these issues can help to improve the patient experience in the ED. 
Acknowledgements: Nil

Competing interests: Nil

Funding: CB is supported by funding from an Australian Government Research Training Program (RTP) scholarship and a Griffith University Health Group top-up scholarship.

Contribution statement: All authors contributed to the conceptualisation of the research. The conduct of the research was primarily undertaken by CB and supported by SL, JC and BG. The reporting of the research was primarily undertaken by CB and supported by SL, JC and BG. All authors contributed to the development of the manuscript, have approved the final version of the manuscript and are responsible for its overall content. 


\section{REFERENCES}

1. Kapoor S, White J, Thorn BE, Block P. Patients presenting to the emergency department with acute pain: The significant role of pain catastrophizing and state anxiety. Pain Med. 2016;17(6):1069-78.

2. Ali S, McGrath T, Drendel AL. An evidence-based approach to minimizing acute procedural pain in the emergency department and beyond. Pediatr Emerg Care. 2016;32(1):36-42; quiz 3-4.

3. Stone E, Winger J. Crowding, boarding, and patient throughput IL, USA: Emergency Nurses Assocation; 2017 [cited 2020 April]. Available from: https://www.ena.org/docs/default-source/resource-library/practice-resources/positionstatements/crowdingboardingandpatientthroughput.pdf?sfvrsn=5fb4e79f_4.

4. Sayah A, Rogers L, Devarajan K, Kingsley-Rocker L, Lobon LF. Minimizing ED waiting times and improving patient flow and experience of care. Emerg Med Int. 2014;2014:981472.

5. Australasian College for Emergency Medicine. Position statement: ambulance ramping West Melbourne, Victoria: ACEM; 2019 [cited 2020 March]. Available from: https://acem.org.au/getmedia/9e6c3e78-8cbc-473c-83df-474f6c1 eecde/S347-Statement-onAmbulance-Ramping-Nov-13.aspx.

6. Hitchcock M, Crilly J, Gillespie B, Chaboyer W, Tippett V, Lind J. The effects of ambulance ramping on emergency department length of stay and in-patient mortality. Australas Emerg Nurs J. 2010;13(1-2):17-24.

7. Cooney DR, Wojcik S, Seth N, Vasisko C, Stimson K. Evaluation of ambulance offload delay at a university hospital emergency department. Int J Emerg Med. 2013;6(1):15. 8. Australasian College for Emergency Medicine. Background paper - access block West Melbourne, Victoria: ACEM; 2014 [cited 2020 March]. Available from: 
https://acem.org.au/getmedia/bb0a89f2-3567-4f49-8317-f07af40d0b1d/S127_v01_BgroundPaper_Mar_14.aspx.

9. Australasian College for Emergency Medicine. Position statement: ED overcrowding West Melbourne, Victoria: ACEM; 2019 [cited 2020 March]. Available from: https://acem.org.au/getmedia/dd609f9a-9ead-473d-9786-d5518cc58298/S57-Statement-onED-Overcrowding-Jul-11-v02.aspx.

10. Bernstein SL, Aronsky D, Duseja R, Epstein S, Handel D, Hwang U, et al. The effect of emergency department crowding on clinically oriented outcomes. Acad Emerg Med. 2009;16(1):1-10.

11. Crilly J, Chaboyer W, Creedy D. Violence towards emergency department nurses by patients. Accid Emerg Nurs. 2004;12(2):67-73.

12. Gordon J, Sheppard LA, Anaf S. The patient experience in the emergency department: a systematic synthesis of qualitative research. Int Emerg Nurs. 2010;18(2):80-8. 13. Sonis JD, Aaronson EL, Lee RY, Philpotts LL, White BA. Emergency department patient experience: a systematic review of the literature. J Patient Exp. 2018;5(2):101-6. 14. Weinick RM, Becker K, Parast L, Stucky BD, Elliott MN, Mathews M, et al. Emergency department patient experience of care survey: development and field test. Rand Health Q. 2014;4(3):5.

15. Graham B, Endacott R, Smith JE, Latour JM. 'They do not care how much you know until they know how much you care': a qualitative metasynthesis of patient experience in the emergency department. Emerg Med J. 2019;36(6).

16. Babbie E. Conceptualization, operationalization, and measurement. In: Evans M, editor. The practice of social research. 12th ed. Belmont, CA: Cengage Learning; 2016. p. 124-56. 
17. Nairn S, Whotton E, Marshal C, Roberts M, Swann G. The patient experience in emergency departments: a review of the literature. Accid Emerg Nurs. 2004;12(3):159-65.

18. Bull C. Patient Satisfaction and Patient Experience are not Interchangeable Concepts. Int J Qual Health Care. 2021.

19. Australian Commission on Safety and Quality in Health Care. What is AHPEQS Canberra: ACSQHC; 2019 [cited 2019 November]. Available from:

https://www.safetyandquality.gov.au/our-work/indicators-measurement-andreporting/patient-experience/about-ahpeqs/what-ahpeqs.

20. Bull C, Byrnes J, Hettiarachchi R, Downes M. A systematic review of the validity and reliability of patient-reported experience measures. Health Serv Res. 2019;54(5):1023-35.

21. Doyle C, Lennox L, Bell D. A systematic review of evidence on the links between patient experience and clinical safety and effectiveness. BMJ Open. 2013;3(1).

22. Dr Foster. The intelligence board 2010: patient experience London, UK: Dr Foster Limited; 2010 [cited 2020 September]. Available from:

http://www.healthcaregovernance.org.au/docs/the-intelligent-board-patient-experience2010.pdf.

23. NHS Institute for Innovation and Improvement. The patient experience book Millburn Hill Road, Coventry: NHS Institute for Innovation and Improvement; 2013 [cited 2020 March]. Available from: https://www.england.nhs.uk/improvement-hub/wpcontent/uploads/sites/44/2017/11/Patient-Experience-Guidance-and-Support.pdf.

24. Schembri S. Experiencing health care service quality: through patients' eyes. Aust Health Rev. 2015;39(1):109-16.

25. Tremblay D, Roberge D, Berbiche D. Determinants of patient-reported experience of cancer services responsiveness. BMC Health Serv Res. 2015;15:425. 
26. Ng JHY, Luk BHK. Patient satisfaction: concept analysis in the healthcare context. Patient Educ Couns. 2019;102(4):790-6.

27. Johansson P, Oleni M, Fridlund B. Patient satisfaction with nursing care in the context of health care: a literature study. Scand J Caring Sci. 2002;16(4):337-44.

28. Pluye P, Hong QN. Combining the power of stories and the power of numbers: mixed methods research and mixed studies reviews. Annu Rev Public Health. 2014;35:29-45.

29. PRISMA. PRISMA: transparent reporting of systematic reviews and meta-analyses Ottawa, Ontario: PRISMA; 2015 [cited 2019 September]. Available from: http://www.prisma-statement.org/.

30. Centre for Reviews and Dissemination University of York. PROSPERO: international prospective register for systematic reviews York, UK: Centre for Reviews and Dissemination University of York; 2019 [cited 2019 September]. Available from: crd.york.ac.uk/prospero/.

[Refer to Supplementary file 5 for additional references cited in-text] 
FIGURE 1: PRISMA flow diagram of study identification and selection

FIGURE 1 legend: PRISMA flow diagram illustrating the electronic database searches and study selection for the systematic mixed studies review

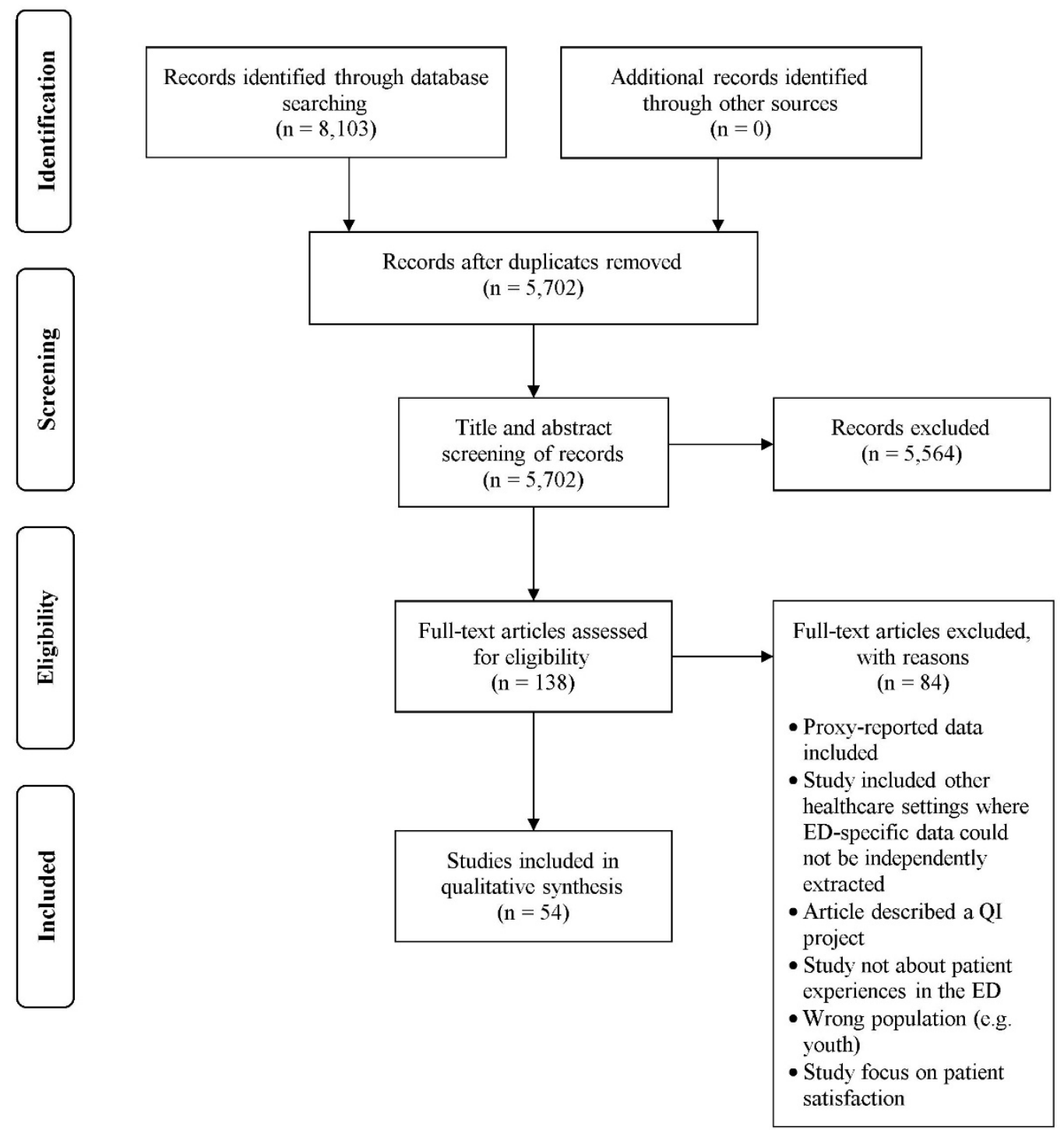




\section{Supplementary file 1: Database searches}

EMBASE (via Elsevier) database search strategy - 16-09-2019

\begin{tabular}{|c|c|c|}
\hline \# & Search terms & Results \\
\hline 1 & $\begin{array}{l}\text { 'patient experience'/exp OR } \\
((\text { patient* OR consumer* OR user*) NEXT/1 experience*):ab,ti OR } \\
\text { ((patient* OR consumer* OR user*) NEXT/1 report* NEXT/1 experience*):ab,ti OR } \\
\text { (experience* NEAR/2 car*):ab,ti }\end{array}$ & 117,666 \\
\hline 2 & $\begin{array}{l}\text { 'emergency ward'/exp OR } \\
\text { (emergency NEXT/1 department*):ab,ti OR } \\
\text { (emergency NEXT/1 unit*):ab,ti OR } \\
\text { (emergency NEXT/1 service*):ab,ti OR } \\
\text { (accident NEAR/2 emergency):ab,ti OR } \\
\text { (emergency NEXT/1 ward*):ab,ti OR } \\
\text { (emergency NEXT/1 room*):ab,ti OR } \\
\text { (emergency NEAR/2 treat*):ab,ti OR } \\
\text { (emergency NEAR/2 car*):ab,ti OR } \\
\text { (urgent NEAR/2 car*):ab,ti OR } \\
\text { (emergency NEAR/2 present*):ab,ti } \\
\text { (emergency NEAR/2 medic*):ab,ti OR } \\
\text { casualty:ab,ti }\end{array}$ & 257,085 \\
\hline 3 & $\begin{array}{l}\# 1 \text { AND \#2 } \\
\text { Limited by: ([article]/lim OR [article in press]/lim OR [data papers]/lim OR [short } \\
\text { survey]/lim); [English]/lim; Publication dates: 2001-current }\end{array}$ & 1,379 \\
\hline
\end{tabular}

$\mathrm{ab}=$ limited to abstract; $\mathrm{t} \mathrm{i}=$ limited to title; $\lim =$ limit 
MEDLINE (via Ovid) database search strategy - 16-09-2019

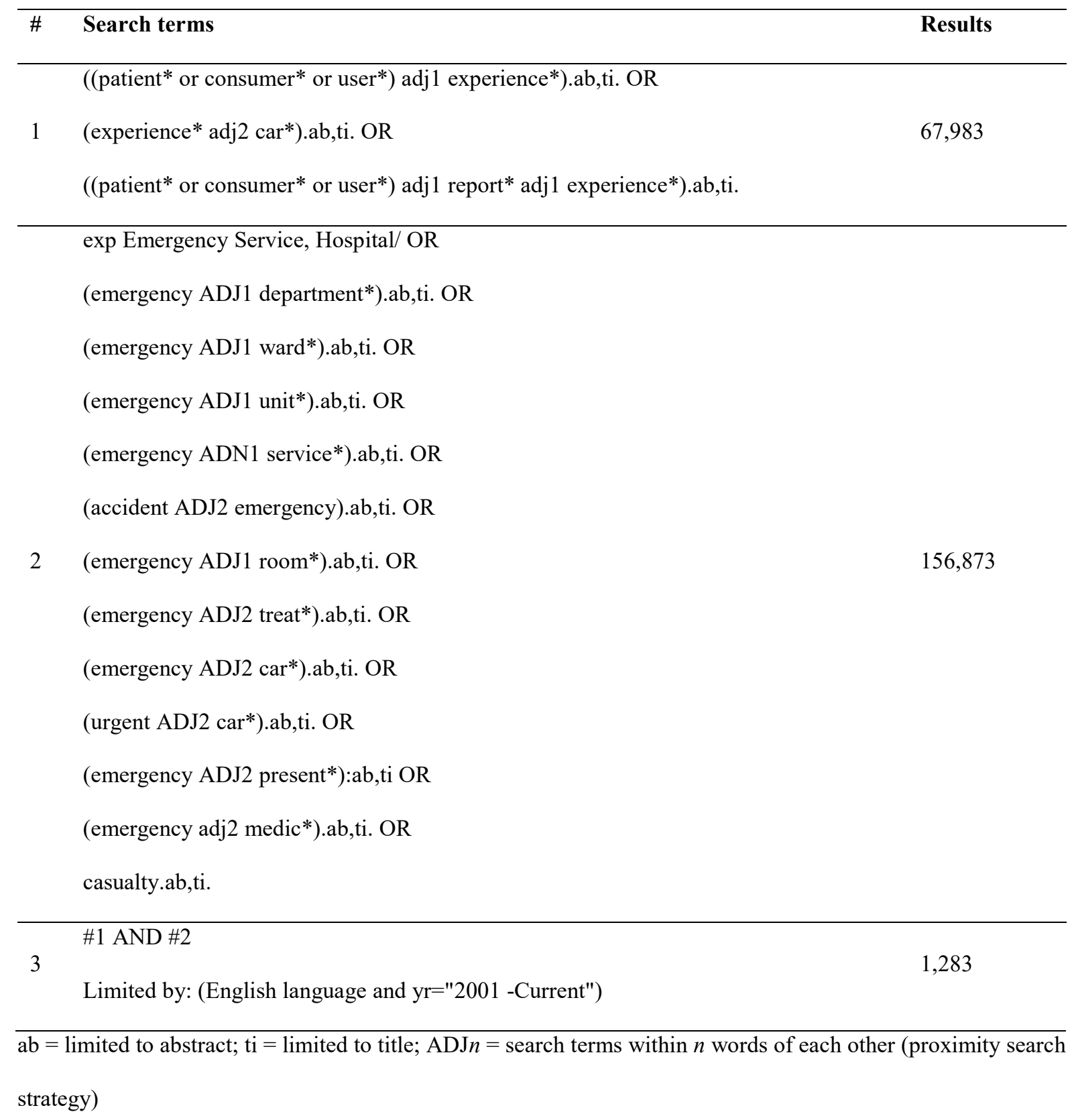


CINAHL (via EBSCOhost) database search strategy - 16-09-2019

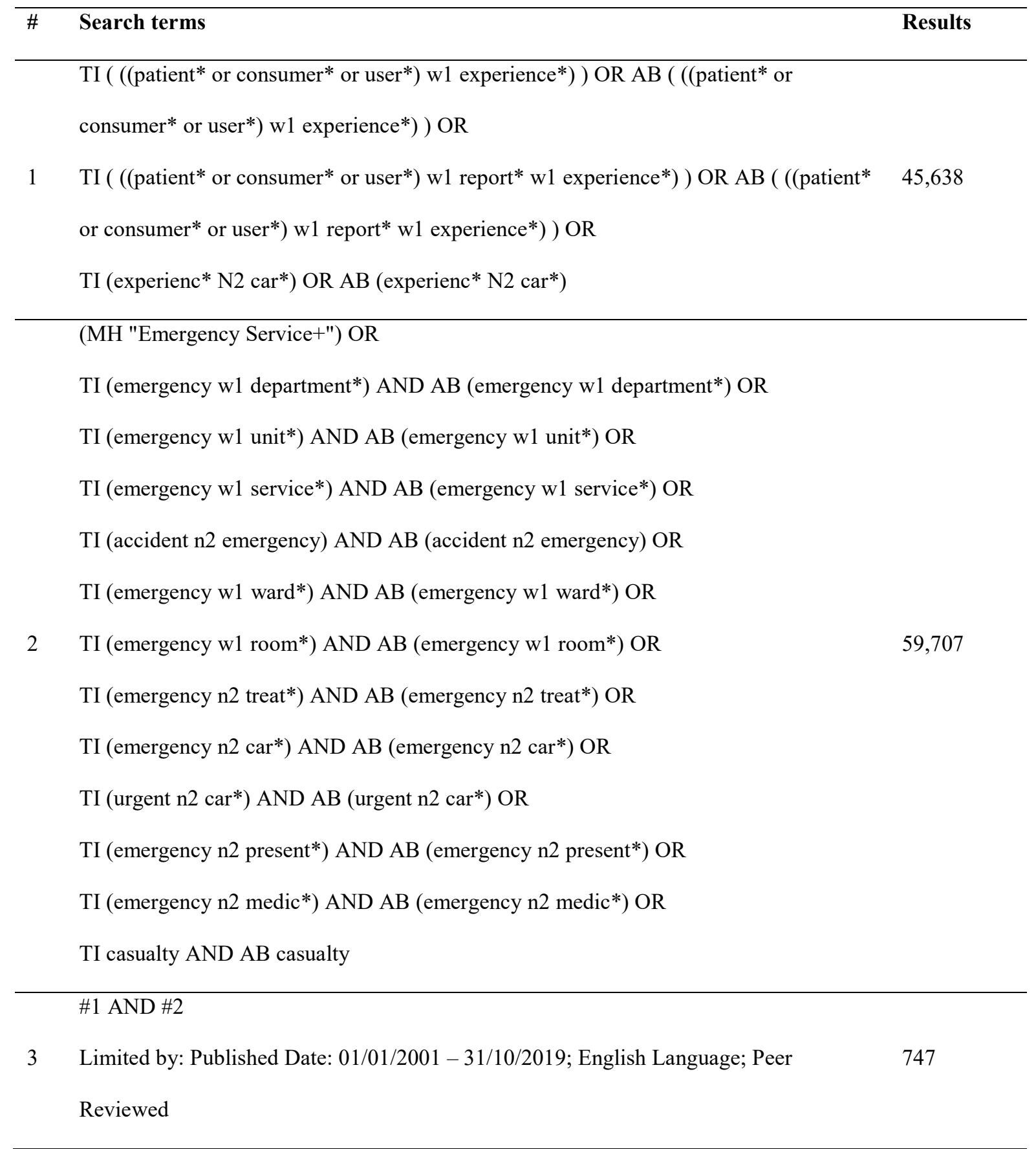
$\mathrm{TI}=$ limited to title; $\mathrm{w}=$ within $n$ words of each other; $\mathrm{AB}=$ limited to abstract; $\mathrm{N}=n$ words apart from one another 
Nursing and Allied Health Database (ProQuest) database search strategy - 20-09-2019

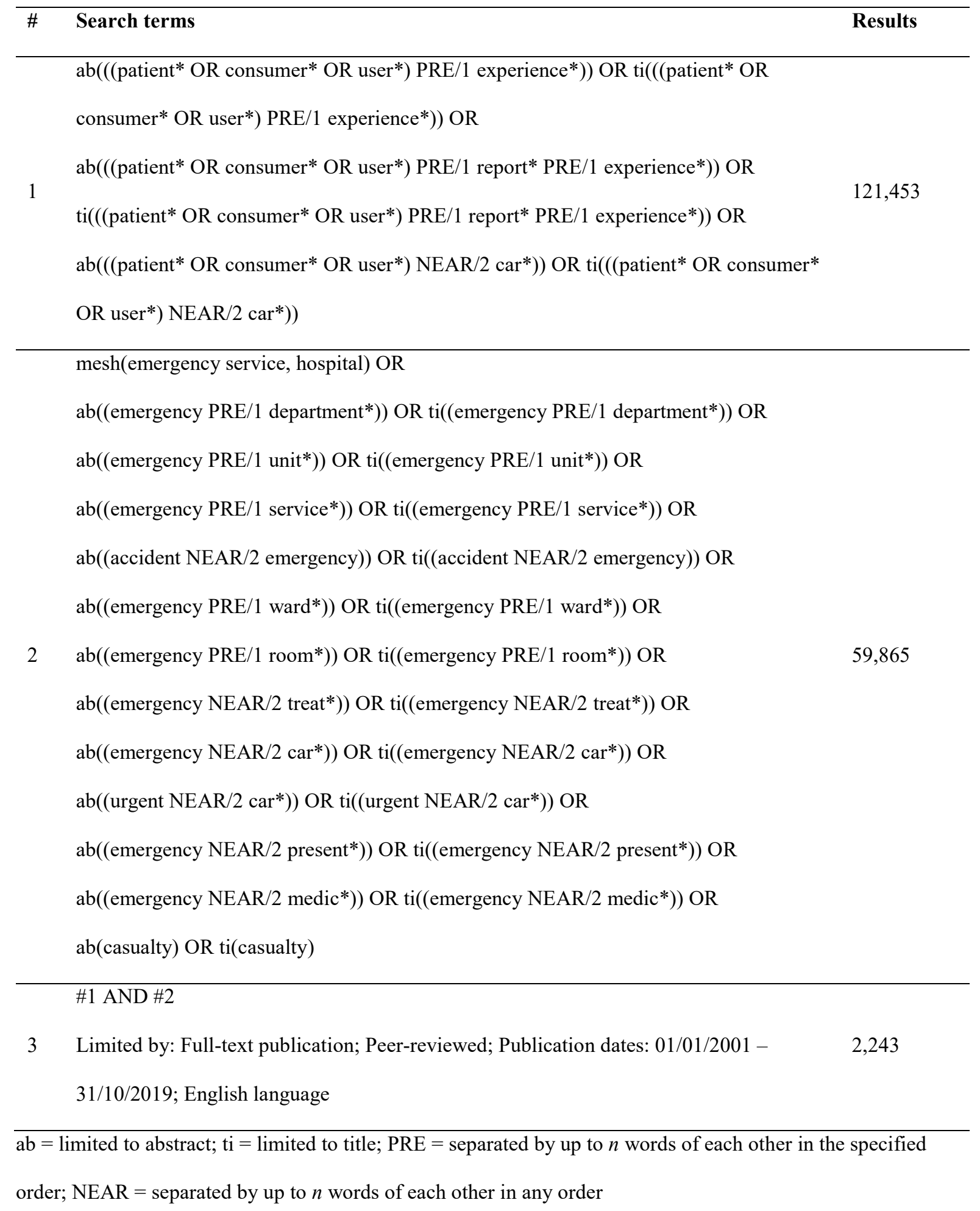


Cochrane Library database search strategy - 20-09-2019

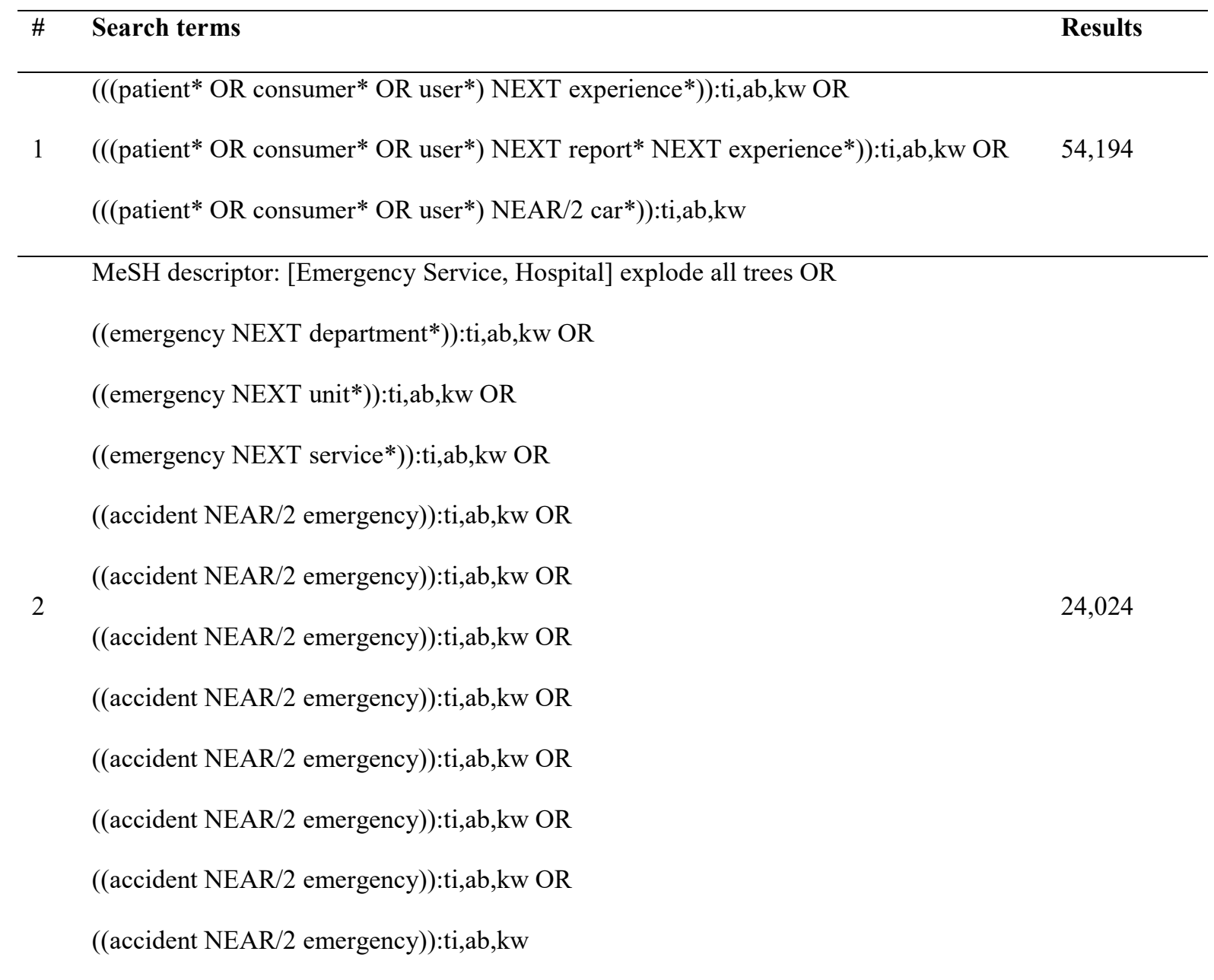

\#1 AND \#2

3 Limited by: Cochrane Library publication date from Jan 2001 to Oct 2019, in Trials, 2,447

Clinical Answers and Special collections

$\overline{\text { NEXT }}=$ words are adjacent to one another in-text; $\mathrm{ab}=$ limited to abstract; $\mathrm{ti}=$ limited to title; $\mathrm{kw}=\mathrm{keyword}$;

NEAR $=$ within $n$ words of each other 
Supplementary File 2: Summary of the included studies $(\mathrm{n}=54)$

\begin{tabular}{|c|c|c|c|}
\hline $\begin{array}{l}\text { Author (Year) } \\
\text { Country }\end{array}$ & Study design & ED Patient Population & Patient Experience Outcomes \\
\hline \multicolumn{4}{|c|}{ QUALITATIVE STUDIES } \\
\hline $\begin{array}{l}\text { Annemans et al (2018) } \\
\text { Belgium }\end{array}$ & $\begin{array}{l}\text { Ethnographic study: face-to-face } \\
\text { interviews, supporting video and } \\
\text { photographic materials }\end{array}$ & $\begin{array}{l}\text { Adult patients - } \\
\text { unspecified }(n=22)\end{array}$ & Themes: Material aspects; Social aspects; Time-related aspects \\
\hline $\begin{array}{l}\text { Arnaert \& Schaack } \\
(2006) \\
\text { Canada }\end{array}$ & $\begin{array}{l}\text { Grounded theory study: face-to- } \\
\text { face semi-structured interviews }\end{array}$ & $\begin{array}{l}\text { Adult patients }- \text { Inuit } \\
\text { people (Aboriginal } \\
\text { people of Canada) }(n=4)\end{array}$ & $\begin{array}{l}\text { Theme: Rationalising the care } \\
\text { - Sub-themes: First impressions of Enrolled Nurse; Perceiving the realities of } \\
\text { the Enrolled Nurse; Appreciating Enrolled Nurse care }\end{array}$ \\
\hline $\begin{array}{l}\text { Arslanian-Engoren \& } \\
\text { Scott (2016) } \\
\text { USA }\end{array}$ & $\begin{array}{l}\text { Descriptive study: semi- } \\
\text { structured focus groups }\end{array}$ & $\begin{array}{l}\text { Adult patients }- \text { female, } \\
\text { acute Myocardial } \\
\text { infarction }(n=14)\end{array}$ & $\begin{array}{l}\text { Theme: Triage experience } \\
\text { - Sub-themes: Arrival mode, ED personnel encounters, follow-up evaluation } \\
\text { and treatment } \\
\text { Theme: Barriers / supports to prompt and accurate recognition of cardiac } \\
\text { symptoms } \\
\text { - Sub-themes: Barriers: time delays, communication issues, age bias, gender } \\
\text { bias; Supports: ED providers, ED status } \\
\text { Theme: Perceptions of disparate treatment } \\
\text { - Sub-themes: No disparate treatment; Disparate treatment; Age; Gender; } \\
\text { Professional/ employment status }\end{array}$ \\
\hline $\begin{array}{l}\text { Baird et al (2018) } \\
\text { USA }\end{array}$ & $\begin{array}{l}\text { Descriptive study: telephone } \\
\text { semi-structured interviews }\end{array}$ & $\begin{array}{l}\text { Adult patients }- \text { female, } \\
\text { early pregnancy loss } \\
(\mathrm{EPL})(\mathrm{n}=10)\end{array}$ & $\begin{array}{l}\text { Theme: Experience in the ER } \\
\text { - Sub-themes: Lack of information and poor communication; Chaotic and } \\
\text { unfriendly environment; Lack of emotional support; Positive aspects of the } \\
\text { ER experience } \\
\text { Theme: Experience after leaving the ER }\end{array}$ \\
\hline $\begin{array}{l}\text { Blackburn et al (2019) } \\
\text { UK (England) }\end{array}$ & $\begin{array}{l}\text { Action research study: face-to- } \\
\text { face interviews }\end{array}$ & $\begin{array}{l}\text { Adult patients }- \\
\text { unspecified }(n=15)\end{array}$ & $\begin{array}{l}\text { Theme: Communication } \\
\text { - Sub-themes: Feeling informed; How long will I have to wait? } \\
\text { Theme: Explanations of treatment and care } \\
\text { - Sub-themes: Explanations of treatment; Explanations of triage } \\
\text { Theme: Written communication }\end{array}$ \\
\hline $\begin{array}{l}\text { Blockley (2003) } \\
\text { New Zealand }\end{array}$ & $\begin{array}{l}\text { Narrative descriptive study: face- } \\
\text { to-face interviews }\end{array}$ & $\begin{array}{l}\text { Adult patients - } \\
\text { unspecified }(n=12)\end{array}$ & $\begin{array}{l}\text { Themes: Feeling powerless; Considerable wait times; Unclear reasons for the } \\
\text { wait time; Anxiety; Inactive involvement }\end{array}$ \\
\hline $\begin{array}{l}\text { Chilsom-Straker et al } \\
(2017) \\
\text { USA }\end{array}$ & $\begin{array}{l}\text { Descriptive study: Thematic } \\
\text { analysis of open-ended responses } \\
\text { to survey questions }\end{array}$ & $\begin{array}{l}\text { Adult patients - trans- } \\
\text { gender/ gender-non- } \\
\text { conforming-experienced } \\
(\mathrm{n}=240)\end{array}$ & $\begin{array}{l}\text { Theme: Self-efficacy } \\
\text { Theme: Power inequality } \\
\text { - Sub-themes: Systems issues; Provider behaviour; Patient-provider encounter }\end{array}$ \\
\hline
\end{tabular}




\begin{tabular}{|c|c|c|c|}
\hline $\begin{array}{l}\text { Christopoulos et al } \\
(2013) \\
\text { USA }\end{array}$ & $\begin{array}{l}\text { Grounded theory study: in-depth, } \\
\text { face-to-face interviews }\end{array}$ & $\begin{array}{l}\text { Adult patients }-\mathrm{HIV} \\
(\mathrm{n}=24)\end{array}$ & $\begin{array}{l}\text { Themes: Physical discomfort/ limited functionality and co-morbid diagnoses; } \\
\text { A wide spectrum of HIV risk perception - shock, betrayal, and guilt; Anxiety } \\
\text { and isolation; Compassionate disclosure with some logistic hurdles; Continuity } \\
\text { between the ED/ Urgent Care (UC) testing site and HIV clinic }\end{array}$ \\
\hline $\begin{array}{l}\text { Considine et al (2010) } \\
\text { Australia }\end{array}$ & $\begin{array}{l}\text { Descriptive study: face-to-face } \\
\text { interviews }\end{array}$ & $\begin{array}{l}\text { Adult patients }-\geq 65 \\
\text { years old }(n=27)\end{array}$ & $\begin{array}{l}\text { Themes: Mixed experiences of waiting; Perceived factors influencing access to } \\
\text { emergency care }\end{array}$ \\
\hline $\begin{array}{l}\text { Doohan \& Saveman } \\
(2015) \\
\text { Sweden }\end{array}$ & $\begin{array}{l}\text { Descriptive study: telephone } \\
\text { interviews }\end{array}$ & $\begin{array}{l}\text { Adult patients }- \text { major } \\
\text { bus crash survivors } \\
(\mathrm{n}=54)\end{array}$ & $\begin{array}{l}\text { Theme: Lack of compassionate care } \\
\text { - Sub-themes: Feeling mistreated; Being left for oneself } \\
\text { Theme: Dissatisfaction with crisis support } \\
\text { Theme: Satisfactory initial care and support }\end{array}$ \\
\hline $\begin{array}{l}\text { Graham J (2002) } \\
\text { UK (England) }\end{array}$ & $\begin{array}{l}\text { Descriptive study: face-to-face } \\
\text { interviews }\end{array}$ & $\begin{array}{l}\text { Adult patients - } \\
\text { unspecified }(n=18)\end{array}$ & Themes: Pain assessment and management; The need for pain management \\
\hline $\begin{array}{l}\text { Harding et al (2015) } \\
\text { Australia }\end{array}$ & $\begin{array}{l}\text { Descriptive study: telephone } \\
\text { interviews }\end{array}$ & $\begin{array}{l}\text { Adult patients }- \text { isolated } \\
\text { musculoskeletal } \\
\text { conditions }(n=25)\end{array}$ & $\begin{array}{l}\text { Themes: Process and level of service provided by the extended scope of } \\
\text { practice (ESOP) physiotherapist; Value of personal attributes of staff; } \\
\text { Confidence in the skills and attributes of ESOP physiotherapist; Timing and } \\
\text { efficiency of the ESOP physiotherapist service; Advice on follow-up care; } \\
\text { Referrals provided if needed; Negative impressions }\end{array}$ \\
\hline $\begin{array}{l}\text { Hermann (2019) } \\
\text { USA }\end{array}$ & $\begin{array}{l}\text { Descriptive study: telephone } \\
\text { interviews }\end{array}$ & $\begin{array}{l}\text { Adult patients - } \\
\text { unspecified }(n=30)\end{array}$ & $\begin{array}{l}\text { Themes: Nonverbal body language; Courtesy and politeness; Reassurance; } \\
\text { Humanism; Attentiveness; Explaining }\end{array}$ \\
\hline $\begin{array}{l}\text { Kaufman (2017) } \\
\text { USA }\end{array}$ & $\begin{array}{l}\text { Descriptive study: face-to-face } \\
\text { interviews; observations }\end{array}$ & $\begin{array}{l}\text { Adult patients }- \text { trauma } \\
\text { resuscitation } \\
(\mathrm{n}[\text { interviews }]=30 \\
\mathrm{n}[\text { observations }]=20)\end{array}$ & $\begin{array}{l}\text { Theme: Internal experience } \\
\text { - Sub-themes: Emotional responses; Physical experience; Nonclinical } \\
\text { concerns } \\
\text { Theme: Interactions with the trauma team } \\
\text { - Sub-themes: Clinical care; Trauma team members; Communication }\end{array}$ \\
\hline $\begin{array}{l}\text { Kilaru et al (2016) } \\
\text { USA }\end{array}$ & $\begin{array}{l}\text { Descriptive study: Framework } \\
\text { and grounded theory analysis of } \\
\text { publicly accessible reviews } \\
\text { posted on Yelp }\end{array}$ & $\begin{array}{l}\text { Adult patients }- \\
\text { unspecified }(\mathrm{n}=533)\end{array}$ & $\begin{array}{l}\text { Themes: Communication with nurses; Communication with doctors; Pain } \\
\text { control; Waiting and efficiency; Decisions to seek care in the emergency } \\
\text { department }\end{array}$ \\
\hline $\begin{array}{l}\text { Liu et al (2015) } \\
\text { USA }\end{array}$ & $\begin{array}{l}\text { Grounded theory study: face-to- } \\
\text { face interviews }\end{array}$ & $\begin{array}{l}\text { Adult patients - boarding } \\
(\mathrm{n}=18)\end{array}$ & $\begin{array}{l}\text { Themes: Awaiting admission to the ED; Comparison with inpatient care; Who } \\
\text { is responsible for patient care; Communication about care; Delay in transfer to } \\
\text { inpatient ward; How to improve boarding experience }\end{array}$ \\
\hline $\begin{array}{l}\text { MacWilliams et al } \\
(2016) \\
\text { Canada }\end{array}$ & $\begin{array}{l}\text { Interpretive phenomenology } \\
\text { study: face-to-face interviews }\end{array}$ & $\begin{array}{l}\text { Adult patients }- \text { female, } \\
\text { actively miscarrying } \\
(\mathrm{n}=8)\end{array}$ & $\begin{array}{l}\text { Themes: Not an illness: A different kind of trauma; Need for } \\
\text { acknowledgement; Leaving the emergency department: What now? }\end{array}$ \\
\hline $\begin{array}{l}\text { Moss et al (2014) } \\
\text { New Zealand }\end{array}$ & $\begin{array}{l}\text { Descriptive study: face-to-face } \\
\text { and telephone interviews }\end{array}$ & $\begin{array}{l}\text { Adult patients }- \text { frequent } \\
\text { presenters }(n=34)\end{array}$ & $\begin{array}{l}\text { Themes: Sustained and enmeshed ethic and duty of care; Consistent duty of } \\
\text { care; Interrupted or mixed duty and ethic of care; Care in breach of both ethic } \\
\text { and duty of care }\end{array}$ \\
\hline
\end{tabular}




\begin{tabular}{|c|c|c|c|}
\hline $\begin{array}{l}\text { O’Brien et al (2004) } \\
\text { Canada }\end{array}$ & $\begin{array}{l}\text { Interpretive phenomenology } \\
\text { study: face-to-face interviews }\end{array}$ & $\begin{array}{l}\text { Adult patients }- \text { trauma } \\
\text { resuscitation }(n=7)\end{array}$ & $\begin{array}{l}\text { Theme: I remember } \\
\text { - Sub-themes: Being frustrated } \\
\text { Theme: I was scared } \\
\text { - Sub-themes: Living through the shock and pain; Feeling alone; Not knowing } \\
\text { Theme: I felt safe } \\
\text { - Sub-themes: They were efficient; Everything went so quick; They gave me } \\
\text { confidence; They were always checking; They were organised; You know } \\
\text { what's going on; They cared about me; It was how they talked; Letting } \\
\text { family friends know I was there; Staff was always there; Touch made me feel } \\
\text { better } \\
\text { Theme: Perceptions of vulnerability }\end{array}$ \\
\hline $\begin{array}{l}\text { Olofsson et al (2012) } \\
\text { Sweden }\end{array}$ & $\begin{array}{l}\text { Descriptive phenomenology } \\
\text { study: face-to-face interviews }\end{array}$ & $\begin{array}{l}\text { Adult patients }-\geq 70 \\
\text { years old with comorbid } \\
\text { chronic conditions }(n=14)\end{array}$ & $\begin{array}{l}\text { Theme: During the triage encounter } \\
\text { - Sub-themes: Prompt and competent care establish confidence; A personal } \\
\text { touch and sincere interest contributes to a feeling of being at the centre of } \\
\text { attention; Attentive listening to the patient established a respectful } \\
\text { relationship } \\
\text { Theme: Beyond the triage encounter } \\
\text { - Sub-themes: Inattentive attitude and indifferent behaviour causes a feeling of } \\
\text { exclusion; Lack of interest in the patient contributes to a feeling of being } \\
\text { neglected and ignored; Failure to listen contributes to frustration and } \\
\text { disappointment in the patients }\end{array}$ \\
\hline $\begin{array}{l}\text { Samuels et al (2018) } \\
\text { USA }\end{array}$ & $\begin{array}{l}\text { Grounded theory study: focus } \\
\text { groups }\end{array}$ & $\begin{array}{l}\text { Adult patients - trans- } \\
\text { gender }(\mathrm{n}=32)\end{array}$ & $\begin{array}{l}\text { Themes: System structure; Care competency; Discrimination and trauma; } \\
\text { Avoidance of emergency care }\end{array}$ \\
\hline $\begin{array}{l}\text { Shoqirat et al (2019) } \\
\text { Jordan }\end{array}$ & $\begin{array}{l}\text { Descriptive study: face-to-face } \\
\text { interviews }\end{array}$ & $\begin{array}{l}\text { Adult patients }- \\
\text { unspecified }(\mathrm{n}=15)\end{array}$ & Theme: Being on ED bed \\
\hline $\begin{array}{l}\text { Skene et al (2017) } \\
\text { UK (England) }\end{array}$ & $\begin{array}{l}\text { Descriptive study: face-to-face } \\
\text { interviews }\end{array}$ & $\begin{array}{l}\text { Adult patients - traumatic } \\
\text { injury }(n=13)\end{array}$ & $\begin{array}{l}\text { Theme: Environmental factors } \\
\text { - Sub-themes: Perspectives on the physical environment; Atmosphere within } \\
\text { the ED; Witnessing the trauma team at work } \\
\text { Theme: Communication styles } \\
\text { - Sub-themes: Informal - humour; Pastoral - reassurance; Formal - } \\
\text { information giving }\end{array}$ \\
\hline $\begin{array}{l}\text { Swallmeh et al (2018) } \\
\text { Republic of Ireland }\end{array}$ & Descriptive study: focus groups & $\begin{array}{l}\text { Adult patients - } \\
\text { unspecified }(n=32)\end{array}$ & $\begin{array}{l}\text { Themes: Reliability; Information; Assurance; Responsiveness; Tangibles; } \\
\text { Empathy }\end{array}$ \\
\hline $\begin{array}{l}\text { Warner et al (2012) } \\
\text { Australia }\end{array}$ & $\begin{array}{l}\text { Descriptive study: face-to-face } \\
\text { interviews }\end{array}$ & $\begin{array}{l}\text { Adult patients - female, } \\
\text { EPL }(n=16)\end{array}$ & $\begin{array}{l}\text { Themes: Staff attitudes and behaviours; Privacy and dignity; Information } \\
\text { provision; Waiting times; Counselling and follow-up }\end{array}$ \\
\hline $\begin{array}{l}\text { Yap et al (2017) } \\
\text { Australia }\end{array}$ & $\begin{array}{l}\text { Phenomenology study: face-to- } \\
\text { face interviews }\end{array}$ & $\begin{array}{l}\text { Adult patients - } \\
\text { behavioural emergency } \\
(\mathrm{n}=13)\end{array}$ & $\begin{array}{l}\text { Theme: Trusting relationships } \\
\text { - Sub-themes: Confidence in care; Sedation as an appropriate treatment; } \\
\text { Insight into own behaviour; Humane treatment }\end{array}$ \\
\hline
\end{tabular}


Theme: Needs and wants following sedation

- Sub-themes: Empathy; Debrief; Addressing concerns; Follow-up

\section{QUANTITATIVE STUDIES}

\begin{tabular}{|c|c|c|c|}
\hline \multicolumn{4}{|c|}{ QUANTITATIVE STUDIES } \\
\hline $\begin{array}{l}\text { Bobrovitz et al (2016) } \\
\text { UK (England) }\end{array}$ & $\begin{array}{l}\text { Cross-sectional study: using the } \\
\text { Quality of Trauma Care Patient- } \\
\text { Reported Experience Measure } \\
\text { (QTAC-PREM) (2012 version) }\end{array}$ & $\begin{array}{l}\text { Adult patients - primary } \\
\text { diagnosis of 'injury' } \\
(\mathrm{n}=607)\end{array}$ & $\begin{array}{l}\text { Themes: Information and communication; Information regarding recovery; } \\
\text { Clinical and ancillary care; Discharge preparedness; Clinical follow-up care }\end{array}$ \\
\hline $\begin{array}{l}\text { Bos et al (2013) } \\
\text { The Netherlands }\end{array}$ & $\begin{array}{l}\text { Cross-sectional study: using the } \\
\text { National Health Service Accident } \\
\text { and Emergency Department } \\
\text { Questionnaire (NHS AEDQ) } \\
\text { (2008 version) }\end{array}$ & $\begin{array}{l}\text { Adult patients - } \\
\text { unspecified }(n=49,646)\end{array}$ & $\begin{array}{l}\text { Themes: Waiting time; Doctors and nurses; Your care and treatment; Hygiene; } \\
\text { Information before discharge; Overall }\end{array}$ \\
\hline $\begin{array}{l}\text { Bos et al (2015a) } \\
\text { The Netherlands }\end{array}$ & $\begin{array}{l}\text { Cross-sectional study: using the } \\
\text { Care Quality Index Accident and } \\
\text { Emergency (CQI A\&E) (2012 } \\
\text { version) }\end{array}$ & $\begin{array}{l}\text { Adult patients - } \\
\text { unspecified }(n=3,483)\end{array}$ & $\begin{array}{l}\text { Themes: Waiting (triage); Waiting (treatment); Problems with the total waiting } \\
\text { time; Perceived acuity; Pain; Referral; Information }\end{array}$ \\
\hline $\begin{array}{l}\text { Bos et al (2015b) } \\
\text { UK (England) }\end{array}$ & $\begin{array}{l}\text { Cross-sectional study: using the } \\
\text { CQI A\&E (2012 version) }\end{array}$ & $\begin{array}{l}\text { Adult patients }- \\
\text { unspecified }(n=4,883)\end{array}$ & $\begin{array}{l}\text { Themes: Information before treatment; Timeliness; Attitude of healthcare } \\
\text { professionals; Professionalism of received care; Information during treatment; } \\
\text { Environment and facilities; Discharge management }\end{array}$ \\
\hline $\begin{array}{l}\text { Bos et al (2016) } \\
\text { The Netherlands and } \\
\text { UK (England) }\end{array}$ & $\begin{array}{l}\text { Cross-sectional study: using the } \\
\text { CQI A\&E (2008 version) and } \\
\text { NHS AEDQ ( } 2008 \text { version) }\end{array}$ & $\begin{array}{l}\text { Adult patients }- \\
\text { unspecified } \\
\text { (n[England }]=43,892 ; \\
\mathrm{n}[\text { Netherlands }]=1,865 \text { ) }\end{array}$ & $\begin{array}{l}\text { Themes: Waiting time; Doctors and nurses; Your care and treatment; Hygiene; } \\
\text { Information before discharge }\end{array}$ \\
\hline $\begin{array}{l}\text { Cambria et al (2019) } \\
\text { USA }\end{array}$ & $\begin{array}{l}\text { Cross-sectional study: using the } \\
\text { Press Ganey Associates (PGA) } \\
\text { Survey (version not reported) }\end{array}$ & $\begin{array}{l}\text { Adult patients }- \\
\text { unspecified }(n=3,429)\end{array}$ & $\begin{array}{l}\text { Themes: Courtesy of the doctor; Degree to which the doctor took the time to } \\
\text { listen to you; Doctor's concern to keep you informed about your treatment; } \\
\text { Doctor's concern for your comfort while treating you }\end{array}$ \\
\hline $\begin{array}{l}\text { Foley et al (2017) } \\
\text { Republic of Ireland }\end{array}$ & $\begin{array}{l}\text { Cross-sectional study: using the } \\
\text { adapted Urgent Care Services } \\
\text { Questionnaire (UCSQ) (version } \\
\text { not reported) }\end{array}$ & $\begin{array}{l}\text { Adult patients }- \\
\text { unspecified }(n=1,205)\end{array}$ & $\begin{array}{l}\text { Themes: Entry into the system; Progress through the system; Patient } \\
\text { convenience of the system }\end{array}$ \\
\hline $\begin{array}{l}\text { Graham C (2018) } \\
\text { UK (England) }\end{array}$ & $\begin{array}{l}\text { Cross-sectional study: using the } \\
\text { NHS AEDQ ( } 2014 \text { version) }\end{array}$ & $\begin{array}{l}\text { Adult patients - } \\
\text { unspecified }(n=39,320)\end{array}$ & $\begin{array}{l}\text { Themes: Waiting time; Doctors and nurses; Your care and treatment; Hygiene; } \\
\text { Information before discharge }\end{array}$ \\
\hline $\begin{array}{l}\text { Hartigan et al (2018) } \\
\text { Republic of Ireland }\end{array}$ & $\begin{array}{l}\text { Pre-post intervention study: using } \\
\text { the Privacy, Dignity and } \\
\text { Confidentiality in the Emergency } \\
\text { Room survey (2018 version) }\end{array}$ & $\begin{array}{l}\text { Adult patients }- \text { female, } \\
\text { pregnant, postnatal and } \\
\text { gynaecological } \\
(\mathrm{n}[\text { pre }]=75 ; \mathrm{n}[\text { post }]=82)\end{array}$ & $\begin{array}{l}\text { Theme: Before refurbishment took place } \\
\text { - Sub-themes: Disappointment; Disgust; Invasion of privacy; Loss of dignity } \\
\text { Theme: After refurbishment took place } \\
\text { - Appreciation; Positive patient experience; The importance of discretion at } \\
\text { all times when caring for patients }\end{array}$ \\
\hline
\end{tabular}




\begin{tabular}{|c|c|c|c|}
\hline $\begin{array}{l}\text { Honeyford et al (2017) } \\
\text { UK (England) }\end{array}$ & $\begin{array}{l}\text { Cross-sectional study: using the } \\
\text { NHS AEDQ (2003, } 2008 \text { and } \\
2014 \text { versions) }\end{array}$ & $\begin{array}{l}\text { Adult patients - } \\
\text { unspecified } \\
(\mathrm{n}[\text { total }]=249,734)\end{array}$ & $\begin{array}{l}\text { Themes: Access and waiting; Safe, high quality, coordinated care; Better } \\
\text { information, more choice; Building closer relationships; Clean, friendly, } \\
\text { comfortable place to be }\end{array}$ \\
\hline $\begin{array}{l}\text { Hoonpongsimanont et } \\
\text { al (2019) } \\
\text { USA }\end{array}$ & $\begin{array}{l}\text { Cross-sectional study: using the } \\
\text { PGA Survey (version not } \\
\text { reported) and a shortened } \\
\text { institutional version of the } \\
\text { Emergency Department Patient } \\
\text { Experience of Care (EDPEC) } \\
\text { survey } 2.0 \text { (2013 version) }\end{array}$ & $\begin{array}{l}\text { Adult patients - } \\
\text { unspecified } \\
(\mathrm{n}[\mathrm{PGA}]=289 \\
\mathrm{n}[\mathrm{EDPEC}]=234)\end{array}$ & $\begin{array}{l}\text { Themes: Courtesy of doctor; Degree to which the doctor took the time to listen } \\
\text { to you; Doctors concern to keep you informed about your treatment; Doctors } \\
\text { concern for your comfort while treating you; How well pain was controlled }\end{array}$ \\
\hline $\begin{array}{l}\text { Hwang et al (2015) } \\
\text { USA }\end{array}$ & $\begin{array}{l}\text { Pre-post intervention study: using } \\
\text { the PGA Survey (version not } \\
\text { reported) }\end{array}$ & $\begin{array}{l}\text { Adult patients }- \text { low } \\
\text { acuity }(\mathrm{n}[\text { pre }]=140 \\
\mathrm{n}[\text { post }]=85)\end{array}$ & $\begin{array}{l}\text { Themes: Wait times; Nurse courtesy; Doctor courtesy; Being kept informed } \\
\text { about delays; Staff caring; Pain control }\end{array}$ \\
\hline $\begin{array}{l}\text { Lenz et al (2017) } \\
\text { Canada }\end{array}$ & $\begin{array}{l}\text { Cross-sectional study: using the } \\
\text { Health Quality Council of } \\
\text { Alberta (HQCA) ED Patient } \\
\text { Experience Survey ( } 2007 \\
\text { version) }\end{array}$ & $\begin{array}{l}\text { Adult patients }- \\
\text { unspecified }(n=3,794)\end{array}$ & $\begin{array}{l}\text { Themes: Staff care; Pain management; Discharge communication; Respect; } \\
\text { Medication communication; Wait time and crowding }\end{array}$ \\
\hline $\begin{array}{l}\text { Mercer et al (2008) } \\
\text { USA }\end{array}$ & $\begin{array}{l}\text { Cross-sectional pilot study: using } \\
\text { an adapted Communication } \\
\text { Assessment Tool - Team (CAT- } \\
\text { T) (version 2008) }\end{array}$ & $\begin{array}{l}\text { Adult patients - } \\
\text { unspecified }(n=81)\end{array}$ & $\begin{array}{l}\text { Theme: Communication } \\
\text { - Items: Greeted me in a way that made me feel comfortable; Treated me with } \\
\text { respect; Showed interest in my ideas about my health; Understood my main } \\
\text { health concerns; Paid attention to me (looked at me, listened carefully; Let } \\
\text { me talk without interruptions; Gave me as much information as I wanted; } \\
\text { Talked in terms I could understand; Checked to be sure I understood } \\
\text { everything; Encouraged me to ask questions; Involved me in decisions as } \\
\text { much as I wanted; Discussed next steps, including any follow-up plans; } \\
\text { Showed care and concern; Spent the right amount of time with me }\end{array}$ \\
\hline $\begin{array}{l}\text { Murrells et al (2013) } \\
\text { UK (England) }\end{array}$ & $\begin{array}{l}\text { Cross-sectional study: using the } \\
\text { Patient Evaluation of Emotional } \\
\text { Care during Hospitalisation } \\
\text { (PEECH) (2008 version) }\end{array}$ & $\begin{array}{l}\text { Adult patients - } \\
\text { unspecified }(\mathrm{n}=159)\end{array}$ & $\begin{array}{l}\text { Themes: Feeling informed; Treated as an individual; Personal interactions; } \\
\text { Feeling valued }\end{array}$ \\
\hline $\begin{array}{l}\text { Olsen \& Sabin (2003) } \\
\text { USA }\end{array}$ & $\begin{array}{l}\text { Cross-sectional study: using an } \\
\text { unnamed 7-item questionnaire } \\
\text { (2003 version) }\end{array}$ & $\begin{array}{l}\text { Adult and paediatric } \dagger \\
\text { patients }- \text { unspecified } \\
(n=440)\end{array}$ & Themes: Privacy; Confidentiality \\
\hline $\begin{array}{l}\text { Parast et al (2019) } \\
\text { USA }\end{array}$ & $\begin{array}{l}\text { Cross-sectional study: using the } \\
\text { EDPEC Discharged to } \\
\text { Community Survey ( } 2018 \\
\text { version) }\end{array}$ & $\begin{array}{l}\text { Adult patients }- \text { not } \\
\text { admitted }(n=3,122)\end{array}$ & $\begin{array}{l}\text { Themes: Getting timely care; How well nurses and doctors communicate; } \\
\text { Communication about medications; Global measures }\end{array}$ \\
\hline
\end{tabular}




\begin{tabular}{|c|c|c|c|}
\hline $\begin{array}{l}\text { Porter et al (2012) } \\
\text { USA }\end{array}$ & $\begin{array}{l}\text { Multisite prospective } \\
\text { longitudinal cohort study: using a } \\
\text { structured medical record review } \\
\text { and an unnamed telephone } \\
\text { survey ( } 2012 \text { version) }\end{array}$ & $\begin{array}{l}\text { Adult patients }- \text { Sickle } \\
\text { Cell Disease }(n=98)\end{array}$ & Themes: Trust; Respect; Pain management \\
\hline $\begin{array}{l}\text { Raleigh (2012) } \\
\text { UK (England) }\end{array}$ & $\begin{array}{l}\text { Cross-sectional study: using the } \\
\text { NHS AEDQ (2008 version) }\end{array}$ & $\begin{array}{l}\text { Adult patients - } \\
\text { unspecified }(n=97,580)\end{array}$ & $\begin{array}{l}\text { Themes: Cleanliness; Dignity and respect; Consistency of communication; } \\
\text { Involvement in decisions; Information provision; Confidence in staff }\end{array}$ \\
\hline $\begin{array}{l}\text { Schwappach et al } \\
(2003) \\
\text { Switzerland }\end{array}$ & $\begin{array}{l}\text { Cross-sectional study: using an } \\
\text { unnamed } 22 \text {-item questionnaire } \\
\text { (2003 version) }\end{array}$ & $\begin{array}{l}\text { Adult and paediatric } \dagger \\
\text { patients }- \text { unspecified } \\
\text { (n[cycle } 1]=2,916 \\
\mathrm{n}[\text { cycle } 2]=3,370)\end{array}$ & $\begin{array}{l}\text { Themes: Patient perceptions of safety and staff technical skills; Aspects of the } \\
\text { ED care structure; Communication; Care and support }\end{array}$ \\
\hline $\begin{array}{l}\text { Sharp et al (2019) } \\
\text { USA }\end{array}$ & $\begin{array}{l}\text { Retrospective cohort study: using } \\
\text { the PGA Survey (version not } \\
\text { reported) }\end{array}$ & $\begin{array}{l}\text { Adult patients }- \\
\text { unspecified }(n=1,012)\end{array}$ & $\begin{array}{l}\text { Themes: Courtesy of doctors who cared for you; Degree to which these doctors } \\
\text { took the time to listen to you; Concern these doctors showed to keep you } \\
\text { informed about your treatment; Concern these doctors showed for your comfort } \\
\text { while treating you; Degree to which these doctors advocated for you care }\end{array}$ \\
\hline $\begin{array}{l}\text { Todd et al (2010) } \\
\text { USA }\end{array}$ & $\begin{array}{l}\text { Cross-sectional study: using an } \\
\text { unnamed } 22 \text {-item telephone } \\
\text { survey measure ( } 2010 \text { version) }\end{array}$ & $\begin{array}{l}\text { Adult patients }- \text { chronic } \\
\text { or recurrent pain }(n=500)\end{array}$ & $\begin{array}{l}\text { Themes: Wait time; Pain management; Dignity and respect; Feeling } \\
\text { understood; Being taken seriously; Information and explanations }\end{array}$ \\
\hline $\begin{array}{l}\text { Yarney \& Atinga } \\
(2017) \\
\text { Ghana }\end{array}$ & $\begin{array}{l}\text { Cross-sectional study: using the } \\
\text { Emergency care quality } \\
\text { structured questionnaire ( } 2017 \\
\text { version) }\end{array}$ & $\begin{array}{l}\text { Adult patients - } \\
\text { unspecified }(n=379)\end{array}$ & $\begin{array}{l}\text { Themes: Social and relational care; Attentive pre-hospitalised care; Ward } \\
\text { quality and privacy; Medical supplies }\end{array}$ \\
\hline \multicolumn{4}{|c|}{ MIXED METHODS STUDIES } \\
\hline $\begin{array}{l}\text { Bos et al (2012) } \\
\text { The Netherlands }\end{array}$ & $\begin{array}{l}\text { Cross-sectional study: survey } \\
\text { instrument development and } \\
\text { psychometric evaluation using } \\
\text { the CQI A\&E ( } 2012 \text { version })\end{array}$ & $\begin{array}{l}\text { Adult patients - } \\
\text { unspecified } \\
\text { (n[QUAL]=17); } \\
\text { n[QUANT] }=304 \text { ) }\end{array}$ & $\begin{array}{l}\text { Themes: Attitude of healthcare professionals; Information and explanation; } \\
\text { Environment of the Accident and Emergency (A\&E); Leaving the A\&E; } \\
\text { General information and rapidity of care }\end{array}$ \\
\hline $\begin{array}{l}\text { Glynn et al (2019) } \\
\text { Canada }\end{array}$ & $\begin{array}{l}\text { Cross-sectional study: survey } \\
\text { instrument administration and } \\
\text { semi-structured interviews }\end{array}$ & $\begin{array}{l}\text { Adult patients - Chronic- } \\
\text { pain (defined as pain } \\
\text { lasting for longer than } 12- \\
\text { weeks) }(\mathrm{n}=12)\end{array}$ & $\begin{array}{l}\text { Theme: Validating experiences } \\
\text { - Sub-themes: Needs were met; Acknowledgement; Compassion; Confidence } \\
\text { Theme: Invalidating experiences } \\
\text { - Sub-themes: Unmet needs; Unacknowledged; Lack of compassion; } \\
\text { Judgement from others; Judgement of self; Waiting; ED lacking medical } \\
\text { information; Inquiry into drug seeking } \\
\text { Theme: Behaviour and attitude management } \\
\text { Theme: Outcomes from ED experiences } \\
\text { - Sub-themes: Admitted; Medical treatment; Pain relief }\end{array}$ \\
\hline $\begin{array}{l}\text { Leppäkoski et al (2011) } \\
\text { Finland }\end{array}$ & $\begin{array}{l}\text { Cross-sectional study: multi- } \\
\text { centre survey instrument }\end{array}$ & $\begin{array}{l}\text { Adult patients - female, } \\
\text { acute physical Intimate }\end{array}$ & $\begin{array}{l}\text { Themes: Physical care environment; Medical treatment; Emotional and } \\
\text { practical support }\end{array}$ \\
\hline
\end{tabular}




\begin{tabular}{|c|c|c|c|}
\hline & $\begin{array}{l}\text { administration and semi- } \\
\text { structured interviews }\end{array}$ & $\begin{array}{l}\text { Partner Violence (IPV) } \\
(\mathrm{n}=35)\end{array}$ & \\
\hline $\begin{array}{l}\text { McCusker et al (2018) } \\
\text { Canada }\end{array}$ & $\begin{array}{l}\text { Cross-sectional study: survey } \\
\text { instrument development and } \\
\text { psychometric evaluation }\end{array}$ & $\begin{array}{l}\text { Adult patients }-\geq 75 \\
\text { years old }(n=481)\end{array}$ & $\begin{array}{l}\text { Themes: Interpersonal care; Communication; Wait times; Family needs; } \\
\text { Transitional care }\end{array}$ \\
\hline $\begin{array}{l}\text { Wild et al (2011) } \\
\text { USA }\end{array}$ & $\begin{array}{l}\text { Cross-sectional study: survey } \\
\text { instrument administration using } \\
\text { the Hospital Consumer } \\
\text { Assessment of Healthcare } \\
\text { Providers and Systems } \\
\text { (HCAHPS) (version not } \\
\text { reported) and face-to-face semi- } \\
\text { structured interviews }\end{array}$ & $\begin{array}{l}\text { Adult patients }- \text { not } \\
\text { admitted }(\mathrm{n}[\text { survey }]=96 \text {; } \\
\mathrm{n}[\text { interviews }]=30)\end{array}$ & Themes: Physician behaviours; Team communication; System issues \\
\hline
\end{tabular}

$\dagger$ Parents were asked to report on behalf of paediatric patients in this study, but because proxy-reporters were not involved in the development of the measure and only items were extracted for the purposes of analysis, this study was retained in the review. ED = Emergency Department; EN = Emergency Nursing; USA = United States of America; EPL = Early Pregnancy Loss; ER = Emergency Room; UK = United Kingdom; HIV = Human Immunodeficiency Virus; $\mathrm{UC}=$ Urgent Care; ESOP = Extended Scope of Practice; QTAC-PREM = Quality of Trauma Care Patient-Reported Experience Measure; NHS = National Health Service; AEDQ = Accident and Emergency Department Questionnaire; CQI = Care Quality Index; A\&E = Accident and Emergency; PGA = Press Ganey Associates; UCSQ = Urgent Care Services Questionnaire; EDPEC = Emergency Department Patient Experiences of Care; HQCA = Health Quality Council of Alberta; CAT-T = Communication Assessment Tool - Team; PEECH = Patient Evaluation of Emotional Care during Hospitalisation; IPV = Intimate Partner Violence; HCAHPS = Hospital Consumer Assessment of Healthcare Providers and Systems. 
Supplementary File 3: Quality appraisal of included studies using the Mixed Methods Appraisal Tool (MMAT) version 2018 (n=54)

\begin{tabular}{|c|c|c|c|c|c|}
\hline \multirow[b]{2}{*}{ Authors (year), country } & \multicolumn{5}{|c|}{ QUALITATIVE } \\
\hline & $\begin{array}{c}\text { Is the qualitative } \\
\text { approach appropriate to } \\
\text { answer the research } \\
\text { question? }\end{array}$ & $\begin{array}{c}\text { Are the qualitative } \\
\text { data collection } \\
\text { methods adequate to } \\
\text { address the research } \\
\text { question? }\end{array}$ & $\begin{array}{l}\text { Are the findings } \\
\text { adequately derived } \\
\text { from the data? }\end{array}$ & $\begin{array}{l}\text { Is the interpretation } \\
\text { of results sufficiently } \\
\text { substantiated by } \\
\text { data? }\end{array}$ & $\begin{array}{c}\text { Is there coherence } \\
\text { between qualitative data } \\
\text { sources, collection, } \\
\text { analysis and } \\
\text { interpretation? }\end{array}$ \\
\hline $\begin{array}{l}\text { Annemans et al (2018) } \\
\text { Belgium }\end{array}$ & $\mathrm{Y}$ & $\mathrm{Y}$ & $\mathrm{Y}$ & $\mathrm{Y}$ & $\mathrm{Y}$ \\
\hline $\begin{array}{l}\text { Arnaert \& Schaack (2006) } \\
\text { Canada }\end{array}$ & $\mathrm{Y}$ & $\mathrm{Y}$ & $\mathrm{Y}$ & CT & $\mathrm{Y}$ \\
\hline $\begin{array}{l}\text { Arslanian-Engoren \& Scott (2016) } \\
\text { USA }\end{array}$ & $\mathrm{Y}$ & $\mathrm{Y}$ & $\mathrm{Y}$ & $\mathrm{Y}$ & $\mathrm{Y}$ \\
\hline $\begin{array}{l}\text { Baird et al (2018) } \\
\text { USA }\end{array}$ & $\mathrm{Y}$ & $\mathrm{Y}$ & $\mathrm{Y}$ & $\mathrm{CT}$ & $\mathrm{Y}$ \\
\hline $\begin{array}{l}\text { Blackburn et al (2019) } \\
\text { UK (England) }\end{array}$ & $\mathrm{Y}$ & $\mathrm{Y}$ & $\mathrm{Y}$ & $\mathrm{Y}$ & $\mathrm{Y}$ \\
\hline $\begin{array}{l}\text { Blockley }(2003) \\
\text { New Zealand }\end{array}$ & $\mathrm{Y}$ & $\mathrm{Y}$ & $\mathrm{Y}$ & $\mathrm{Y}$ & $\mathrm{Y}$ \\
\hline $\begin{array}{l}\text { Chilsom-Straker et al (2017) } \\
\text { USA }\end{array}$ & $\mathrm{Y}$ & $\mathrm{Y}$ & $\mathrm{Y}$ & $\mathrm{Y}$ & $\mathrm{Y}$ \\
\hline $\begin{array}{l}\text { Christopoulos et al (2013) } \\
\text { USA }\end{array}$ & $\mathrm{Y}$ & $\mathrm{Y}$ & $\mathrm{Y}$ & $\mathrm{Y}$ & $\mathrm{Y}$ \\
\hline $\begin{array}{l}\text { Considine et al (2010) } \\
\text { Australia }\end{array}$ & $\mathrm{Y}$ & $\mathrm{Y}$ & $\mathrm{Y}$ & $\mathrm{Y}$ & $\mathrm{Y}$ \\
\hline $\begin{array}{l}\text { Doohan \& Saveman (2015) } \\
\text { Sweden }\end{array}$ & $\mathrm{Y}$ & $\mathrm{Y}$ & $\mathrm{Y}$ & $\mathrm{Y}$ & $\mathrm{Y}$ \\
\hline $\begin{array}{l}\text { Graham J (2002) } \\
\text { UK (England) }\end{array}$ & $\mathrm{Y}$ & $\mathrm{Y}$ & $\mathrm{Y}$ & $\mathrm{Y}$ & $\mathrm{Y}$ \\
\hline $\begin{array}{l}\text { Harding et al (2015) } \\
\text { Australia }\end{array}$ & $\mathrm{Y}$ & $\mathrm{Y}$ & $\mathrm{Y}$ & $\mathrm{Y}$ & $\mathrm{Y}$ \\
\hline $\begin{array}{l}\text { Hermann et al (2019) } \\
\text { USA }\end{array}$ & $\mathrm{Y}$ & $\mathrm{Y}$ & $\mathrm{Y}$ & $\mathrm{Y}$ & $\mathrm{Y}$ \\
\hline $\begin{array}{l}\text { Kaufman et al (2017) } \\
\text { USA }\end{array}$ & $\mathrm{Y}$ & $\mathrm{Y}$ & $\mathrm{Y}$ & $\mathrm{Y}$ & $\mathrm{Y}$ \\
\hline $\begin{array}{l}\text { Kilaru et al (2016) } \\
\text { USA }\end{array}$ & $\mathrm{Y}$ & $\mathrm{Y}$ & $\mathrm{Y}$ & $\mathrm{Y}$ & $\mathrm{Y}$ \\
\hline
\end{tabular}




\begin{tabular}{|c|c|c|c|c|c|}
\hline $\begin{array}{l}\text { Liu et al (2015) } \\
\text { USA }\end{array}$ & $\mathrm{Y}$ & $\mathrm{Y}$ & $\mathrm{Y}$ & $\mathrm{Y}$ & $\mathrm{Y}$ \\
\hline $\begin{array}{l}\text { MacWilliams et al (2016) } \\
\text { Canada }\end{array}$ & $\mathrm{Y}$ & $\mathrm{Y}$ & $\mathrm{Y}$ & $\mathrm{Y}$ & $\mathrm{Y}$ \\
\hline $\begin{array}{l}\text { Moss et al (2014) } \\
\text { New Zealand }\end{array}$ & $\mathrm{Y}$ & $\mathrm{Y}$ & $\mathrm{Y}$ & $\mathrm{Y}$ & $\mathrm{Y}$ \\
\hline $\begin{array}{l}\text { O'Brien et al (2004) } \\
\text { Canada }\end{array}$ & $\mathrm{Y}$ & $\mathrm{Y}$ & $\mathrm{Y}$ & $\mathrm{Y}$ & $\mathrm{Y}$ \\
\hline $\begin{array}{l}\text { Olofsson et al (2012) } \\
\text { Sweden }\end{array}$ & $\mathrm{Y}$ & $\mathrm{Y}$ & $\mathrm{Y}$ & $\mathrm{Y}$ & $\mathrm{Y}$ \\
\hline $\begin{array}{l}\text { Samuels et al (2018) } \\
\text { USA }\end{array}$ & $\mathrm{Y}$ & $\mathrm{Y}$ & $\mathrm{Y}$ & $\mathrm{Y}$ & $\mathrm{Y}$ \\
\hline $\begin{array}{l}\text { Shoqirat et al (2019) } \\
\text { Jordan }\end{array}$ & $\mathrm{Y}$ & $\mathrm{Y}$ & $\mathrm{Y}$ & $\mathrm{Y}$ & $\mathrm{Y}$ \\
\hline $\begin{array}{l}\text { Skene et al (2017) } \\
\text { UK (England) }\end{array}$ & $\mathrm{Y}$ & $\mathrm{Y}$ & $\mathrm{Y}$ & $\mathrm{Y}$ & $\mathrm{Y}$ \\
\hline $\begin{array}{l}\text { Swallmeh et al (2018) } \\
\text { Republic of Ireland }\end{array}$ & $\mathrm{Y}$ & $\mathrm{Y}$ & $\mathrm{Y}$ & $\mathrm{Y}$ & $\mathrm{Y}$ \\
\hline $\begin{array}{l}\text { Warner et al (2012) } \\
\text { Australia }\end{array}$ & $\mathrm{Y}$ & $\mathrm{Y}$ & $\mathrm{Y}$ & $\mathrm{Y}$ & $\mathrm{Y}$ \\
\hline \multirow[t]{3}{*}{$\begin{array}{l}\text { Yap et al (2017) } \\
\text { Australia }\end{array}$} & $\mathrm{Y}$ & $\mathrm{Y}$ & $\mathrm{Y}$ & $\mathrm{Y}$ & $\mathrm{Y}$ \\
\hline & \multicolumn{5}{|c|}{ QUANTITATIVE DESCRIPTIVE } \\
\hline & $\begin{array}{l}\text { Is the sampling strategy } \\
\text { relevant to address the } \\
\text { research question? }\end{array}$ & $\begin{array}{l}\text { Is the sample } \\
\text { representative of the } \\
\text { target population? }\end{array}$ & $\begin{array}{c}\text { Are the measurements } \\
\text { appropriate? }\end{array}$ & $\begin{array}{c}\text { Is the risk of } \\
\text { nonresponse bias } \\
\text { low? }\end{array}$ & $\begin{array}{l}\text { Is the statistical analysis } \\
\text { appropriate to answer } \\
\text { the research question? }\end{array}$ \\
\hline $\begin{array}{l}\text { Bobrovitz et al (2016) } \\
\text { UK (England) }\end{array}$ & $\mathrm{Y}$ & $\mathrm{CT}$ & $\mathrm{Y}$ & $\mathrm{Y}$ & $\mathrm{Y}$ \\
\hline $\begin{array}{l}\text { Bos et al (2013) } \\
\text { The Netherlands }\end{array}$ & $\mathrm{Y}$ & $\mathrm{Y}$ & $\mathrm{Y}$ & $\mathrm{Y}$ & $\mathrm{Y}$ \\
\hline $\begin{array}{l}\text { Bos et al (2015a) } \\
\text { The Netherlands }\end{array}$ & $\mathrm{Y}$ & $\mathrm{Y}$ & $\mathrm{Y}$ & $\mathrm{Y}$ & $\mathrm{Y}$ \\
\hline $\begin{array}{l}\text { Bos et al (2015b) } \\
\text { UK (England) }\end{array}$ & $\mathrm{Y}$ & $\mathrm{Y}$ & $\mathrm{Y}$ & $\mathrm{Y}$ & $\mathrm{Y}$ \\
\hline $\begin{array}{l}\text { Bos et al (2016) } \\
\text { The Netherlands and UK (England) }\end{array}$ & $\mathrm{Y}$ & $\mathrm{Y}$ & $\mathrm{Y}$ & $\mathrm{Y}$ & $\mathrm{Y}$ \\
\hline $\begin{array}{l}\text { Cambria et al (2019) } \\
\text { USA }\end{array}$ & $\mathrm{Y}$ & $\mathrm{N}$ & $\mathrm{Y}$ & $\mathrm{N}$ & Y \\
\hline
\end{tabular}




\begin{tabular}{|c|c|c|c|c|c|}
\hline $\begin{array}{l}\text { Foley et al (2017) } \\
\text { Republic of Ireland }\end{array}$ & $\mathrm{Y}$ & $\mathrm{Y}$ & $\mathrm{Y}$ & $\mathrm{CT}$ & $\mathrm{Y}$ \\
\hline $\begin{array}{l}\text { Graham C (2018) } \\
\text { UK (England) }\end{array}$ & $\mathrm{Y}$ & $\mathrm{Y}$ & $\mathrm{Y}$ & $\mathrm{Y}$ & $\mathrm{Y}$ \\
\hline $\begin{array}{l}\text { Hartigan et al (2018) } \\
\text { Republic of Ireland }\end{array}$ & $\mathrm{Y}$ & $\mathrm{Y}$ & $\mathrm{N}$ & $\mathrm{CT}$ & $\mathrm{Y}$ \\
\hline $\begin{array}{l}\text { Honeyford et al (2017) } \\
\text { UK (England) }\end{array}$ & $\mathrm{Y}$ & $\mathrm{Y}$ & $\mathrm{Y}$ & $\mathrm{Y}$ & $\mathrm{Y}$ \\
\hline $\begin{array}{l}\text { Hoonpongsimanont et al (2019) } \\
\text { USA }\end{array}$ & $\mathrm{Y}$ & $\mathrm{Y}$ & $\mathrm{CT}$ & $\mathrm{CT}$ & $\mathrm{CT}$ \\
\hline $\begin{array}{l}\text { Hwang et al (2015) } \\
\text { USA }\end{array}$ & $\mathrm{Y}$ & $\mathrm{Y}$ & $\mathrm{Y}$ & $\mathrm{N}$ & $\mathrm{Y}$ \\
\hline $\begin{array}{l}\text { Lenz et al (2017) } \\
\text { Canada }\end{array}$ & $\mathrm{Y}$ & $\mathrm{CT}$ & $\mathrm{Y}$ & $\mathrm{Y}$ & $\mathrm{Y}$ \\
\hline $\begin{array}{l}\text { Mercer et al (2008) } \\
\text { USA }\end{array}$ & $\mathrm{Y}$ & $\mathrm{N}$ & $\mathrm{Y}$ & $\mathrm{Y}$ & $\mathrm{CT}$ \\
\hline $\begin{array}{l}\text { Murrells et al (2013) } \\
\text { UK (England) }\end{array}$ & $\mathrm{Y}$ & $\mathrm{CT}$ & $\mathrm{N}$ & $\mathrm{N}$ & $\mathrm{Y}$ \\
\hline $\begin{array}{l}\text { Olsen \& Sabin (2003) } \\
\text { USA }\end{array}$ & $\mathrm{Y}$ & $\mathrm{N}$ & $\mathrm{N}$ & $\mathrm{Y}$ & $\mathrm{Y}$ \\
\hline $\begin{array}{l}\text { Parast et al (2019) } \\
\text { USA }\end{array}$ & $\mathrm{Y}$ & $\mathrm{N}$ & $\mathrm{Y}$ & $\mathrm{N}$ & $\mathrm{Y}$ \\
\hline $\begin{array}{l}\text { Porter et al (2012) } \\
\text { USA }\end{array}$ & $\mathrm{Y}$ & $\mathrm{CT}$ & $\mathrm{CT}$ & $\mathrm{CT}$ & $\mathrm{Y}$ \\
\hline $\begin{array}{l}\text { Raleigh et al (2012) } \\
\text { UK (England) }\end{array}$ & $\mathrm{Y}$ & $\mathrm{Y}$ & $\mathrm{Y}$ & $\mathrm{CT}$ & $\mathrm{Y}$ \\
\hline $\begin{array}{l}\text { Schwappach et al (2003) } \\
\text { Switzerland }\end{array}$ & $\mathrm{Y}$ & $\mathrm{Y}$ & $\mathrm{Y}$ & $\mathrm{N}$ & $\mathrm{Y}$ \\
\hline $\begin{array}{l}\text { Sharp et al (2019) } \\
\text { USA }\end{array}$ & $\mathrm{Y}$ & $\mathrm{N}$ & $\mathrm{Y}$ & $\mathrm{N}$ & $\mathrm{Y}$ \\
\hline $\begin{array}{l}\text { Todd et al (2010) } \\
\text { USA }\end{array}$ & $\mathrm{Y}$ & $\mathrm{CT}$ & $\mathrm{CT}$ & $\mathrm{N}$ & $\mathrm{Y}$ \\
\hline $\begin{array}{l}\text { Yarney \& Atinga (2017) } \\
\text { Ghana }\end{array}$ & $\mathrm{Y}$ & $\mathrm{CT}$ & $\mathrm{Y}$ & $\mathrm{CT}$ & $\mathrm{Y}$ \\
\hline & \multicolumn{5}{|c|}{ MIXED METHODS } \\
\hline & $\begin{array}{l}\text { Is there an adequate } \\
\text { rationale for using a } \\
\text { mixed methods design to }\end{array}$ & $\begin{array}{l}\text { Are the different } \\
\text { components of the } \\
\text { study effectively }\end{array}$ & $\begin{array}{c}\text { Are the outputs of the } \\
\text { integration of } \\
\text { qualitative and }\end{array}$ & $\begin{array}{l}\text { Are divergences and } \\
\text { inconsistencies } \\
\text { between quantitative }\end{array}$ & $\begin{array}{l}\text { Do the different } \\
\text { components of the study } \\
\text { adhere to the quality }\end{array}$ \\
\hline
\end{tabular}




\begin{tabular}{|c|c|c|c|c|c|}
\hline & $\begin{array}{c}\text { address the research } \\
\text { question? }\end{array}$ & $\begin{array}{l}\text { integrated to answer } \\
\text { the research question? }\end{array}$ & $\begin{array}{l}\text { quantitative } \\
\text { components } \\
\text { adequately } \\
\text { interpreted? }\end{array}$ & $\begin{array}{c}\text { and qualitative } \\
\text { results adequately } \\
\text { addressed? }\end{array}$ & $\begin{array}{l}\text { criteria of each tradition } \\
\text { of the methods involved? }\end{array}$ \\
\hline $\begin{array}{l}\text { Bos et al (2012) } \\
\text { The Netherlands }\end{array}$ & $\mathrm{Y}$ & $\mathrm{CT}$ & $\mathrm{CT}$ & $\mathrm{Y}$ & $\mathrm{Y}$ \\
\hline $\begin{array}{l}\text { Glynn et al (2019) } \\
\text { Canada }\end{array}$ & $\mathrm{N}$ & $\mathrm{CT}$ & $\mathrm{CT}$ & $\mathrm{Y}$ & $\mathrm{N}$ \\
\hline $\begin{array}{l}\text { Leppäkoski et al (2011) } \\
\text { Finland }\end{array}$ & $\mathrm{N}$ & $\mathrm{CT}$ & $\mathrm{CT}$ & $\mathrm{Y}$ & $\mathrm{CT}$ \\
\hline $\begin{array}{l}\text { McCusker et al (2018) } \\
\text { Canada }\end{array}$ & $\mathrm{N}$ & $\mathrm{CT}$ & $\mathrm{CT}$ & $\mathrm{Y}$ & $\mathrm{Y}$ \\
\hline $\begin{array}{l}\text { Wild et al (2011) } \\
\text { USA }\end{array}$ & $\mathrm{CT}$ & $\mathrm{CT}$ & $\mathrm{CT}$ & $\mathrm{Y}$ & $\mathrm{Y}$ \\
\hline
\end{tabular}




\section{Supplementary File 4: Patient experience defined by included studies}

\begin{tabular}{|c|c|}
\hline $\begin{array}{l}\text { Author (year) } \\
\text { Country }\end{array}$ & Patient experience definition \\
\hline $\begin{array}{l}\text { Bos et al (2012) } \\
\text { The Netherlands }\end{array}$ & $\begin{array}{l}\text { It is preferable to measure patients' experiences rather than their satisfaction, as they have shown to be more objective and to yield more detailed } \\
\text { information for quality improvement. One theory is that satisfaction is a multi-dimensional concept, partly based on expectations and personal } \\
\text { preferences. ( } \mathrm{pg} 2)[58]\end{array}$ \\
\hline $\begin{array}{l}\text { Bos et al (2016) } \\
\text { The Netherlands and } \\
\text { UK (England) }\end{array}$ & $\begin{array}{l}\text { The questionnaire seeks to measure patients' experiences rather than their satisfaction. Satisfaction is based on two components: expectations (or } \\
\text { 'needs') and experiences. Expectations are related to personal preferences, which make quality of care difficult to measure. Therefore, it is } \\
\text { preferable to measure experiences, which have been shown to be more objective and to yield more detailed information for quality improvement. } \\
\text { (pg 774)[61] }\end{array}$ \\
\hline $\begin{array}{l}\text { Lenz et al (2017) } \\
\text { Canada }\end{array}$ & $\begin{array}{l}\text { Authors defined the domains addressed by the HQCA ED patient experience survey: } \\
\text { 1. Staff Care: how well ED staff discussed and explained a patient's medical condition, plan, and results. How well they listened to patients' } \\
\text { concerns. How much did patients trust their physicians and feel that they were involved in decision-making. } \\
\text { 2. Pain Management: how effectively and efficiently pain was managed by ED staff. } \\
\text { 3. Discharge Communication: how well staff discussed discharge plans, follow-up care, danger signs to be aware of, and how well they addressed } \\
\text { any concerns prior to discharge. } \\
\text { 4. Respect: how respectful were staff of patients and their families. } \\
\text { 5. Medication Communication: how effectively medication use, and side effects were explained to patients. } \\
\text { 6. Wait Time and Crowding: how did wait time and crowding influence the patient experience. (pg 374)[66] }\end{array}$ \\
\hline $\begin{array}{l}\text { Murrells et al (2013) } \\
\text { UK (England) }\end{array}$ & $\begin{array}{l}\text {...patient experience is commonly considered to be shaped by the behaviours and actions of healthcare staff including showing compassion, } \\
\text { empathy and responsiveness to a patient's needs, values and preferences. It is also seen to relate to aspects of patient's physical needs and } \\
\text { comfort, as well as emotional support, such as relieving fear and anxiety. A further aspect is 'seeing the patient as an individual person' and } \\
\text { involving them and their families or carers in decisions about their own treatment or care. A patient's experience has also been linked to } \\
\text { organisational factors, including service co-ordination and integration of care. } \\
\text { A good patient experience is therefore multidimensional concerning first, 'functional' aspects of care (such as arranging the transfer of patients } \\
\text { to other services, administering medication and helping patients to manage and control pain), 'transactional' aspects of care (in which the } \\
\text { individual is cared 'for', e.g., meeting the preferences of the patient as far as timings and locations of appointments are concerned) and } \\
\text { 'relational' aspects of care (where the individual is cared 'about', e.g., care is approached as part of an ongoing relationship with the patient). } \\
\text { (pg 2)[97] }\end{array}$ \\
\hline $\begin{array}{l}\text { Swallmeh et al } \\
(2018) \\
\text { Republic of Ireland }\end{array}$ & $\begin{array}{l}\text { Surveying patient experience identifies service improvement, an activity that requires specific data about what happened, not just data on whether } \\
\text { patients were satisfied with what happened... patient experience surveys ask patients questions about what occurred during their healthcare } \\
\text { experience ... examples include: 'When you had important questions to ask a doctor, did you get answers you could understand?'... questions can } \\
\text { elicit responses that provide information identifying where in the process problems may reside and what can be done to improve patient care. (pg } \\
\text { 3)[86] }\end{array}$ \\
\hline
\end{tabular}




\section{Supplementary file 5: Additional references cited in-text}

31. Institute of Medicine Committee on Quality of Health Care in America. Crossing the quality chasm: a new health system for the 21 st century. Washington (DC): National Academies Press (US); 2001.

32. Hong QN, Gonzalez-Reyes A, Pluye P. Improving the usefulness of a tool for appraising the quality of qualitative, quantitative and mixed methods studies, the mixed methods appraisal tool (MMAT). J Eval Clin Pract. 2018;24(3):459-67.

33. Koo TK, Li MY. A guideline of selecting and reporting intraclass correlation coefficients for reliability research. J Chiropr Med. 2016;15(2):155-63.

34. Thomas J, Harden A. Methods for the thematic synthesis of qualitative research in systematic reviews. BMC Med Res Methodol. 2008;8:45.

35. Bos N, Seccombe IJ, Sturms LM, Stellato R, Schrijvers AJP, Stel HF. A comparison of the quality of care in accident and emergency departments in England and the Netherlands as experienced by patients. Health Expect. 2016;19(3):773-84.

36. Bos N, Sturms LM, Schrijvers AJ, van Stel HF. The Consumer Quality index (CQindex) in an accident and emergency department: development and first evaluation. BMC Health Serv Res. 2012;12:284.

37. Lenz K, McRae A, Wang D, Higgins B, Innes G, Cook T, et al. Slow or swift, your patients' experience won't drift: absence of correlation between physician productivity and the patient experience. CJEM. 2017;19(5):372-80.

38. Murrells T, Robert G, Adams M, Morrow E, Maben J. Measuring relational aspects of hospital care in England with the 'patient evaluation of emotional care during hospitalisation' (PEECH) survey questionnaire. BMJ Open. 2013;3(1).

39. Swallmeh E, Byers V, Arisha A. Informing quality in emergency care: understanding patient experiences. Int J Health Care Qual Assur. 2018;31(7):704-17. 
40. Olofsson P, Carlstrom ED, Back-Pettersson S. During and beyond the triage encounter: chronically ill elderly patients' experiences throughout their emergency department attendances. Int Emerg Nurs. 2012;20(4):207-13.

41. Moss C, Nelson K, Connor M, Wensley C, McKinlay E, Boulton A. Patient experience in the emergency department: inconsistencies in the ethic and duty of care. J Clin Nurs. 2015;24(1-2):275-88.

42. Samuels EA, Tape C, Garber N, Bowman S, Choo EK. "Sometimes you feel like the freak show": a qualitative assessment of emergency care experiences among transgender and gender-nonconforming patients. Ann Emerg Med. 2018;71(2):170-82.e1.

43. Yap CYL, Knott JC, Kong DCM, Gerdtz M, Stewart K, Taylor DM. Don't Label Me: A Qualitative Study of Patients' Perceptions and Experiences of Sedation During Behavioral Emergencies in the Emergency Department. Acad Emerg Med. 2017;24(8):957-67.

44. Blockley C. Experiences of first time hospitalisation for acute illness. Nurs Prax N Z. $2008 ; 19(2): 19-26$.

45. Glynn BA, Brule M, Kenny SL, Khoo EL, Shergill Y, Smyth CE, et al. Understanding the High Frequency Use of the Emergency Department for Patients With Chronic Pain: A Mixed-Methods Study. J Healthc Qual. 2019;41(4):195-211.

46. Blackburn J, Ousey K, Goodwin E. Information and communication in the emergency department. Int Emerg Nurs. 2019;42:30-5.

47. Hermann RM, Long E, Trotta RL. Improving Patients' Experiences Communicating With Nurses and Providers in the Emergency Department. J Emerg Nurs. 2019;45(5):523-30. 48. Skene I, Pott J, McKeown E. Patients' experience of trauma care in the emergency department of a major trauma centre in the UK. Int Emerg Nurs. 2017;35:1-6.

49. O'Brien JA, Fothergill-Bourbonnais F. The experience of trauma resuscitation in the emergency department: themes from seven patients. J Emerg Nurs. 2004;30(3):216-24. 
50. Mercer LM, Tanabe P, Pang PS, Gisondi MA, Courtney DM, Engel KG, et al. Patient perspectives on communication with the medical team: pilot study using the Communication Assessment Tool-Team (CAT-T). Patient Educ Couns. 2008;73(2):220-3.

51. Bos N, Sizmur S, Graham C, van Stel HF. The accident and emergency department questionnaire: a measure for patients' experiences in the accident and emergency department. BMJ Qual Saf. 2013;22(2):139-46.

52. Bos N, Sturms LM, Stellato RK, Schrijvers AJ, van Stel HF. The Consumer Quality Index in an accident and emergency department: internal consistency, validity and discriminative capacity. Health Expect. 2015;18(5):1426-38.

53. Cambria B, Basile J, Youssef E, Greenstein J, Chacko J, Hahn B, et al. The effect of practice settings on individual Doctor Press Ganey scores: A retrospective cohort review. Am J Emerg Med. 2019;37(9):1618-21.

54. Graham C. People's experiences of hospital care on the weekend: secondary analysis of data from two national patient surveys. BMJ Qual Saf. 2018;27(6):455-63.

55. Hoonpongsimanont W, Sahota PK, Chen Y, Nguyen M, Louis C, Pena J, et al. Emergency department patient experience: Same location, same provider, different scores by different survey methods. World J Emerg Med. 2019;10(3):138-44.

56. Kilaru AS, Meisel ZF, Paciotti B, Ha YP, Smith RJ, Ranard BL, et al. What do patients say about emergency departments in online reviews? A qualitative study. BMJ Qual Saf. 2016;25(1):14-24.

57. Parast L, Mathews M, Tolpadi A, Elliott M, Flow-Delwiche E, Becker K. National Testing of the Emergency Department Patient Experience of Care Discharged to Community Survey and Implications for Adjustment in Scoring. Med Care. 2019;57(1):42-8. 
58. Raleigh VS, Frosini F, Sizmur S, Graham C. Do some trusts deliver a consistently better experience for patients? An analysis of patient experience across acute care surveys in English NHS trusts. BMJ Qual Saf. 2012;21(5):381-90.

59. Sharp B, Johnson J, Hamedani AG, Hakes EB, Patterson BW. What Are We Measuring? Evaluating Physician-Specific Satisfaction Scores Between Emergency Departments. West J Emerg Med. 2019;20(3):454-9.

60. Wild DM, Kwon N, Dutta S, Tessier-Sherman B, Woddor N, Sipsma HL, et al. Who's behind an HCAHPS score? Jt Comm J Qual Patient Saf. 2011;37(10):461-8.

61. Foley C, Droog E, Boyce M, Healy O, Browne J. Patient experience of different regional models of urgent and emergency care: a cross-sectional survey study. BMJ Open. 2017;7(3):e013339.

62. Todd KH, Cowan P, Kelly N, Homel P. Chronic or recurrent pain in the emergency department: national telephone survey of patient experience. West J Emerg Med. 2010;11(5):408-15.

63. Warner A, Saxton A, Indig D, Fahy K, Horvat L. Women's experience of early pregnancy care in the emergency department: a qualitative study. Australas Emerg Nurs J. 2012;15:86-92.

64. Arnaert A, Schaack G. Cultural awareness of Inuit patients' experiences with emergency nursing care. Accid Emerg Nurs. 2006;14(2):97-103.

65. Leppakoski T, Paavilainen E, Astedt-Kurki P. Experiences of emergency care by the women exposed to acute physical intimate partner violence from the Finnish perspective. Int Emerg Nurs. 2011;19(1):27-36.

66. Arslanian-Engoren C, Scott LD. Women's perceptions of biases and barriers in their myocardial infarction triage experience. Heart Lung. 2016;45(3):166-72. 
67. Bobrovitz N, Santana MJ, Kline T, Kortbeek J, Widder S, Martin K, et al. Multicenter validation of the Quality of Trauma Care Patient-Reported Experience Measure (QTACPREM). J Trauma Acute Care Surg. 2016;80(1):111-8.

68. Kaufman EJ, Richmond TS, Wiebe DJ, Jacoby SF, Holena DN. Patient Experiences of Trauma Resuscitation. JAMA Surg. 2017;152(9):843-50.

69. Harding P, Prescott J, Block L, O'Flynn AM, Burge AT. Patient experience of expanded-scope-of-practice musculoskeletal physiotherapy in the emergency department: a qualitative study. Aust Health Rev. 2015;39(3):283-9.

70. Honeyford K, Greaves F, Aylin P, Bottle A. Secondary analysis of hospital patient experience scores across England's National Health Service - How much has improved since 2005? PLoS One. 2017;12(10):e0187012.

71. Olsen JC, Sabin BR. Emergency department patient perceptions of privacy and confidentiality. J Emerg Med. 2003;25(3):329-33.

72. Baird S, Gagnon MD, deFiebre G, Briglia E, Crowder R, Prine L. Women's experiences with early pregnancy loss in the emergency room: A qualitative study. Sex Reprod Healthc. 2018;16:113-7.

73. Doohan I, Saveman BI. Need for compassion in prehospital and emergency care: a qualitative study on bus crash survivors' experiences. Int Emerg Nurs. 2015;23(2):115-9. 74. Chisolm-Straker M, Jardine L, Bennouna C, Morency-Brassard N, Coy L, Egemba MO, et al. Transgender and Gender Nonconforming in Emergency Departments: A Qualitative Report of Patient Experiences. Transgend Health. 2017;2(1):8-16. 75. McCusker J, Cetin-Sahin D, Cossette S, Ducharme F, Vadeboncoeur A, Vu M, et al. How older adults experience an emergency department visit: development and validation of measures. Ann Emerg Med. 2018;71(6):755-66. 
76. Bos N, van Stel H, Schrijvers A, Sturms L. Waiting in the Accident and Emergency Department: Exploring Problematic Experiences. South Med J. 2015;108(10):613-20.

77. Hwang CE, Lipman GS, Kane M. Effect of an emergency department fast track on Press-Ganey patient satisfaction scores. West J Emerg Med. 2015;16(1):34-8.

78. Schwappach DL, Blaudszun A, Conen D, Ebner H, Eichler K, Hochreutener MA. 'Emerge': Benchmarking of clinical performance and patients' experiences with emergency care in Switzerland. Int J Qual Health Care. 2003;15(6):473-85.

79. Shoqirat N, Mahasneh D, Khresheh R, Singh C, Al-Momani MM, Al-Kalaldeh M. Factors influencing patients' experiences of pain management in the emergency department. Can J Nurs Res. 2020;52(1):25-30.

80. Annemans M, Van Audenhove C, Vermolen H, Heylighen A. The Role of Space in Patients' Experience of an Emergency Department: A Qualitative Study. J Emerg Nurs. 2018;44(2):139-45.

81. Christopoulos KA, Massey AD, Lopez AM, Hare CB, Johnson MO, Pilcher CD, et al. Patient perspectives on the experience of being newly diagnosed with HIV in the emergency department/urgent care clinic of a public hospital. PLoS One. 2013;8(8):e74199.

82. MacWilliams K, Hughes J, Aston M, Field S, Moffatt FW. Understanding the Experience of Miscarriage in the Emergency Department. J Emerg Nurs. 2016;42(6):504-12. 83. Considine J, Smith RJ, Hill K, Weiland T, Gannon J, Behm C, et al. Older peoples' experience of accessing emergency care. Australas Emerg Nurs J. 2010;13(3):61-9. 84. Graham J. Adult patients' perceptions of pain management at triage: a small exploratory study. Accid Emerg Nurs. 2002;10(2):78-86.

85. Porter J, Feinglass J, Artz N, Hafner J, Tanabe P. Sickle cell disease patients' perceptions of emergency department pain management. J Natl Med Assoc. 2012;104(910):449-54. 
86. Yarney L, Atinga RA. Patients' perspectives of emergency care quality and priorities for care improvement. Int J Health Gov. 2017;22(4):234-45.

87. Hartigan L, Cussen L, Meaney S, O'Donoghue K. Patients' perception of privacy and confidentiality in the emergency department of a busy obstetric unit. BMC Health Serv Res. 2018;18(1):978.

88. Liu S, Milne L, Yun B, Walsh K. The boarding experience from the patient perspective: the wait. Emerg Med J. 2015;32(11):854-9.

89. Wolf JA, Niederhauser V, Marshburn D, LaVela SL. Defining patient experience. Patient Exp J. 2014;1(1):7-19.

90. Soremekun OA, Takayesu JK, Bohan SJ. Framework for analyzing wait times and other factors that impact patient satisfaction in the emergency department. J Emerg Med. 2011;41(6):686-92.

91. Rhodes KV, Vieth T, He T, Miller A, Howes DS, Bailey O, et al. Resuscitating the physician-patient relationship: Emergency department communication in an academic medical center. Ann Emerg Med. 2004;44(3):262-7.

92. Knopp R, Rosenzweig S, Bernstein E, Totten V. Physician-patient communication in the emergency department, part 1. Acad Emerg Med. 1996;3(11):1065-9.

93. Chang BP, Carter E, Suh EH, Kronish IM, Edmondson D. Patient treatment in ED hallways and patient perception of clinician-patient communication. Am J Emerg Med. 2016;34(6):1163-4.

94. Hermann RM, Long E, Trotta RL. Improving patients' experiences communicating with nurses and providers in the emergency department. J Emerg Med. 2019;45(5):523-30. 95. Byrne G, Heyman R. Patient anxiety in the accident and emergency department. J Clin Nurs. 1997;6(4):289-95. 
96. Diercks DB, Roe MT, Chen AY, Peacock FW, Kirk DJ, Pollack CV, et al. Prolonged emergency eepartment stays of non-ST-segment-elevation myocardial infarction patients are associated with worse adherence to the American College of Cardiology/American Heart Association guidelines for management and increased adverse events. Ann Emerg Med. 2007;50(5):489-96

97. Forero R, McCarthy S, Hillman K. Access block and emergency department overcrowding. Crit Care. 2011;15(2):216-.

98. Kelly AM, Bryant M, Cox L, Jolley D. Improving emergency department efficiency by patient streaming to outcomes-based teams. Aust Health Rev. 2007;31(1):16-21.

99. Nystrom M, Dahlberg K, Carlsson G. Non-caring encounters at an emergency care unit - a life-world hermeneutic analysis of an efficiency-driven organization. Int J Nurs Stud. $2003 ; 40(7): 761-9$.

100. Redfern E, Brown R, Vincent CA. Identifying vulnerabilities in communication in the emergency department. Emerg Med J. 2009;26(9):653-7.

101. Berry LL, Danaher TS, Beckham D, Awdish RLA, Mate KS. When patients and their families feel like hostages to health care. Mayo Clin Proc. 2017;92(9):1373-81.

102. Shay LA, Lafata JE. Where is the evidence? A systematic review of shared decision making and patient outcomes. Med Decis Making. 2015;35(1):114-31.

103. Probst MA, Kanzaria HK, Schoenfeld EM, Menchine MD, Breslin M, Walsh C, et al. Shared decision making in the emergency department: a guiding framework for clinicians. Ann Emerg Med. 2017;70(5):688-95.

104. Melnick ER, Probst MA, Schoenfeld E, Collins SP, Breslin M, Walsh C, et al. Development and testing of shared decision making interventions for use in emergency care: a research agenda. Acad Emerg Med. 2016;23(12):1346-53. 
105. Schoenfeld EM, Goff SL, Downs G, Wenger RJ, Lindenauer PK, Mazor KM. A qualitative analysis of patients' perceptions of shared decision making in the emergency department: "let me know I have a choice". Acad Emerg Med. 2018;25(7):716-27.

106. Kanzaria HK, Booker-Vaughns J, Itakura K, Yadav K, Kane BG, Gayer C, et al. Dissemination and implementation of shared decision making into clinical practice: a research agenda. Acad Emerg Med. 2016;23(12):1368-79.

107. Kanzaria HK, Brook RH, Probst MA, Harris D, Berry SH, Hoffman JR. Emergency physician perceptions of shared decision-making. Acad Emerg Med. 2015;22(4):399-405. 108. Schoenfeld EM, Goff SL, Elia TR, Khordipour ER, Poronsky KE, Nault KA, et al. The physician-as-stakeholder: an exploratory qualitative analysis of physicians' motivations for using shared decision making in the emergency department. Acad Emerg Med. 2016;23(12):1417-27.

109. Probst MA, Kanzaria HK, Frosch DL, Hess EP, Winkel G, Ngai KM, et al. Perceived appropriateness of shared decision-making in the emergency department: a survey study. Acad Emerg Med. 2016;23(4):375-81.

110. Flynn D, Knoedler MA, Hess EP, Murad MH, Erwin PJ, Montori VM, et al. Engaging patients in health care decisions in the emergency department through shared decisionmaking: a systematic review. Acad Emerg Med. 2012;19(8):959-67.

111. Dodd KW, Berman A, Brown J, Carr BG, Dunn P, Escobedo M, et al. Funding research in emergency department shared decision making: a summary of the 2016 academic emergency medicine consensus conference panel discussion. Acad Emerg Med. 2016;23(12):1340-5.

112. Maughan BC, Meisel ZF, Venkatesh AK, Lin MP, Perry WM, 2nd, Schuur JD, et al. Health policy and shared decision making in emergency care: a research agenda. Acad Emerg Med. 2016;23(12):1380-5. 
113. Australian Institute for Health and Welfare. Emergency department care 2017-18: Australian hospital statistics. Canberra: AIHW; 2018. Contract No.: Health services series no. 89. Cat no. HSE 216.

114. Australian Bureau of Statistics. 3101.0 - Australian demographic statistics, Dec 2019 Canberra: ABS; 2019 [updated 18 June 2020; cited 2020 August]. Available from: https://www.abs.gov.au/AUSSTATS/abs@.nsf/mf/3101.0.

115. Moore G, Gerdtz M, Manias E, Hepworth G, Dent A. Socio-demographic and clinical characteristics of re-presentation to an Australian inner-city emergency department: implications for service delivery. BMC Public Health. 2007;7:320.

116. Vitali R, Ficarra L, Lo Presti ML. The waiting experience in the emergency room: A qualitative analysis of the patient waiting emotional state. Acta Medica Mediterr. 2013;29(1):77-81.

117. Dahlen I, Westin L, Adolfsson A. Experience of being a low priority patient during waiting time at an emergency department. Psychol Res Behav Manag. 2012;5:1-9.

118. Thompson DA, Yarnold PR, Williams DR, Adams SL. Effects of actual waiting time, perceived waiting time, information delivery, and expressive quality on patient satisfaction in the emergency department. Ann Emerg Med. 1996;28(6):657-65.

119. Cassidy-Smith TN, Baumann BM, Boudreaux ED. The disconfirmation paradigm: Throughput times and emergency department patient satisfaction. J Emerg Med. 2007;32(1):7-13.

120. Hedges JR, Trout A, Magnusson AR. Satisfied Patients Exiting the Emergency Department (SPEED) study. Acad Emerg Med. 2002;9(1):15-21.

121. Spechbach H, Rochat J, Gaspoz JM, Lovis C, Ehrler F. Patients' time perception in the waiting room of an ambulatory emergency unit: A cross-sectional study. BMC Emerg Med. 2019;19(1):41. 